Boston University School of Law Scholarly Commons at Boston University School of Law

9-1995

\title{
"The Sacred Rights of the Weak": Pain, Sympathy, and the Culture of Individual Rights in Antebellum America
}

Elizabeth B. Clark

Follow this and additional works at: https://scholarship.law.bu.edu/clark_pubs

Part of the Legal History Commons

\section{Recommended Citation}

Elizabeth B. Clark, "The Sacred Rights of the Weak": Pain, Sympathy, and the Culture of Individual Rights in Antebellum America, 82 J. Am. Hist. 463 (1995). 


\title{
"The Sacred Rights of the Weak": Pain, Sympathy, and the Culture of Individual Rights in Antebellum America
}

\author{
Elizabeth B. Clark
}

In 1835 an antislavery sympathizer leaving a lecture by Theodore Dwight Weld went home to dream that she was transported above the world; looking down at the United States, she saw "multitudes of sable figures, bending beneath a scorching sun - their backs lacerated by the whip - scourged, maimed, loaded with ironssubject to every insult - and exposed to every gust of unbridled passions." "The dreamer, a Mrs. Sturges, drew from many discourses in describing her lengthy dream, but the fundamental trope of her visionary narrative was the story of the suffering slave, a trope that in the 1830 s began to play a crucial role in an unfolding language of individual rights.

Slaves had suffered for many generations by the time Mrs. Sturges had her vision, but in the 1830s their stories became newly audible and visible in the North, where graphic portrayals of slaves' subjective experience of physical pain emerged as common antislavery fare. Augmented in the 1840 s and 1850 s by slave narratives and sentimental fiction, this genre, with its critique of interpersonal violence and sexual abuse, served as a vehicle for new arguments for a "right" to bodily integrity. Only by understanding changing cultural and religious conceptions of the nature of pain, the value of suffering, and the duty of compassion can we understand how, by the later nineteenth century, legal standards came to incorporate (albeit imperfectly) the idea that to be free of physical coercion and deliberately inflicted pain was an essential human right.

Cruelty was not a novel concept in the nineteenth century, but antislavery writing helped expand the definition of cruel behavior. For, despite the constitutional ban

Elizabeth B. Clark is an associate professor at Boston University Law School and the author of Women, Church, and State: Religion and the Culture of Individual Rights in Nineteenth-Century America, forthcoming from University of North Carolina Press. This paper has benefitted greatly from discussions with colleagues too numerous to mention and from invaluable help from Boston University's Pappas Law Library and the Boston Athenaeum Library.

\footnotetext{
${ }^{1}$ Robert H. Abzug, Passionate Liberator: Theodore Dwight Weld and the Dilemma of Reform (New York, 1980), 130.
} 
on "cruel and unusual punishment" by the state laid down by the Founders, no similar norm or legal check prevailed within such status relationships as those of master and slave or husband and wife. Relying on such hierarchical relationships to maintain social order in the absence of a standing police force, the legal system largely protected the meting out of brutal assault under the cloak of "discipline." Delegitimizing the "right" to private violence against persons became an abolitionist goal, and the movement fostered a popular rights consciousness that ultimately helped to establish protections at law for the persons of freed slaves and, later, of wives and to narrow the class of relationships in which violence was sanctioned. ${ }^{2}$

Recent historiography has debated the role of capitalism in the formation of humane values. But in the first half of the nineteenth century, it was Protestant ministers, not merchants, who preached the value of "an interest in the sufferings of others who are at a distance from us. . . . [an effort] to extend our sympathies beyond 'the little limits of our own State and neighborhood." A closer look at the immediate religious and cultural contexts of American antislavery might reveal what David Brion Davis calls "mediating structures or institutions between abstract market forces and individual cognition." Shifting our view to these mediating figures and forces would also help explain the periodicity of humane movements in America. While Thomas Haskell dates the advent of market capitalism from 1750, antislavery sentiment did not rise consistently from 1750 on. Rather, after a brief swell of protest in the late 1700s, confined largely to communities of Friends, the movement became quiescent until the early 1830s. By 1830 the trend toward market capitalism had long been in motion, but only in the thirty years before the Civil War did reformers mount an aggressive and highly public assault on violence as a tool of governance in the master-slave relationship. ${ }^{3}$

This article traces the story of the suffering slave in the antebellum United States as emblematic of a shift in moral convention by looking first at the range of uses made of that story; then by providing a context for it in changing notions about pain derived from liberal Protestant thought and in new imperatives for sympathy made popular by evangelical revivalism; and finally by examining how anecdotes of brutality helped foster arguments for the rights of the person in the context of relationships of authority and dependence.

Conjoining liberal and evangelical teachings for this analysis verges on egregious lumping. Certainly, such "liberal" denominations as the Society of Friends and the

\footnotetext{
${ }^{2}$ For the persistence in America of a lay rights consciousness, see Hendrik Hartog, "The Constitution of Aspiration and 'The Rights That Belong to Us All,'” Journal of American History, 74 (Dec. 1987), 1013-34.

${ }^{3}$ James Freeman Clarke, A Sermon Delivered in Amory Hall, on Thanksgiving Day, November 24, 1842 (Boston, 1843), 4; David Brion Davis, "The Perils of Doing History by Ahistorical Abstraction," in The Antislavery Debate: Capitalism and Abolitionism as a Problem in Historical Interpretation, ed. Thomas Bender (Berkeley, 1992), 290-309, esp. 290; Thomas L. Haskell, "Capitalism and the Origins of the Humanitarian Sensibility, Part 2," ibid., 136-60; James D. Essig, The Bonds of Wickedness: American Evangelicals against Slavery, 1770-1808 (Philadelphia, 1982); Richard Brodhead, Cultures of Letters: Scenes of Reading and Writing in Nineteenth-Century America (Chicago, 1993), 13-14.
} 
Unitarians openly challenged orthodox Reformed theology. But American Protestantism across the board was undergoing liberalization as the Calvinist tide ebbed, allowing the creation of a mainstream Protestant culture broadly receptive to certain Christian humanist ideals. ${ }^{4}$

Similarly, the abolitionists whose rhetoric this paper explores had feet in many different religious camps; but theological categories, while significant, are not watertight, nor do they comprehensively describe the world view of any given abolitionist. Historians have rightly stressed the substantive and strategic quarrels that split the antislavery movement along lines sometimes labeled "liberal" and "evangelical." But abolitionists also shared a core belief that the whipping of slaves by masters represented an indefensible exercise of arbitrary authority and that representations of such events should provoke a sympathetic response from right-thinking Christians. Protestant teachings that we would label both "liberal" and "evangelical" contributed to that belief.'

\section{Recounting the Suffering of Slaves, 1830-1860}

In the 1830s, the first decade of insurgent abolitionism, the gruesome tribulations of the body became a staple of antislavery literature. ${ }^{6}$ Indeed, abolitionists must have thought this genre important to employ it as often as they did: speeches, letters, flyers, tracts, minutes, and proceedings from the 1830s and 1840s are filled with examples, from brief descriptions to lengthy accounts of "the beatings, the brandings, the iron yokes, the croppings, the mutilations, the hunger, want, and nakedness." Northern readers of antislavery literature could hardly avoid the tales, carefully selected to appall their sensibilities, of the mistress who beat her cook's head in with the fire shovel because dinner was burned or the master who had an elderly woman - the nanny of his youth-brutally whipped. Another commonly told story was of a nephew of Thomas Jefferson, who one evening took a sulky slave and, working up from the feet, cropped off small bits and fed them to the fire; by morning the carcass was consumed. ${ }^{7}$

${ }^{4}$ D. H. Meyer, The Instructed Conscience: The Shaping of the American National Ethic (Philadelphia, 1972), 25-26; Ann Douglas, The Feminization of American Culture (New York, 1978), 143-96.

5 Staughton Lynd, Intellectual Origins of American Radicalism (New York, 1968), 139-40. On the important commonalities among abolitionists, see Ronald G. Walters, The Antislavery Appeal: American Abolitionism after 1830 (Baltimore, 1976). For religious characterizations of abolitionists, see, for example, Lawrence J. Friedman, Gregarious Saints: Self and Community in American Abolitionism, 1830-1870 (New York, 1982); Bertram WyattBrown, Lewis Tappan and the Evangelical War against Slavery (Cleveland, 1969); Abzug, Passionate Liberator; and Robert H. Abzug, Cosmos Crumbling: American Reform and the Religious Imagination (New York, 1994), 127-62.

${ }^{6}$ Earlier works prefigured this approach: see Jesse Torrey, Portraiture of Domestic Slavery in the United States (Philadelphia, 1817); and [David Walker], Walker's Appeal (Boston, 1829). Colonization societies also dwelled on physical cruelty to slaves: see Samuel J. May, Some Recollections of Our Antislavery Conflict (1869; New York, 1968), 74.

${ }^{7}$ Liberty Bell(Boston, 1844), 5; Lydia Maria Child, Authentic Anecdotes of American Slavery (Newburyport, Mass., 1838), 12; David L. Child, The Despotism of Freedom; or, The Tyranny and Cruelty of American Republican Slave-Masters, Shown To Be the Worst in the World (Boston, 1833), 28, 42; John Rankin, Letters On American Slavery (1837; Westport, 1970), 62-64. 


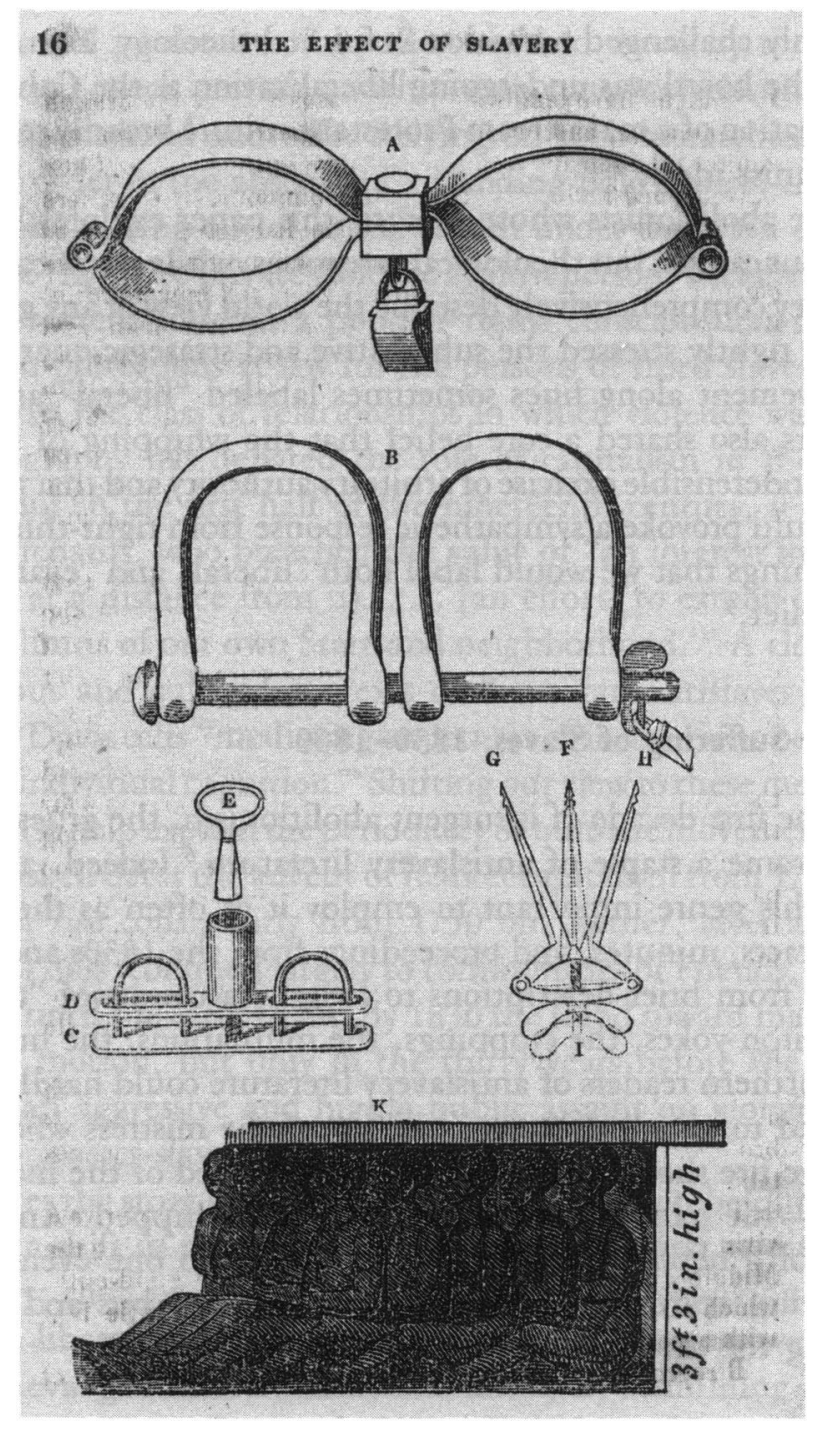

Instruments of slave "discipline," from Lydia Maria Child, An Appeal in Favor of That Class of Americans Called Africans (Boston, 1833).

Courtesy Boston Atberaeum.

Two of the most influential antislavery works of the 1830 s were classics of this genre. Lydia Maria Child's An Appeal In Favor of That Class of Americans Called A fricans, published in 1833, was the first major antislavery tract whose stated mission was to "follow the poor slave through his wretched wanderings, in order to give some idea of his physical suffering, his mental and moral degradation." Six years 
later, Weld, unable to ignore the physical mark left on the body by arbitrary power, undertook to collect and authenticate reports of abuse from across the South. Working with Sarah and Angelina Grimké, he compiled a catalog of atrocities, American Slavery As It Is, which remained the best-selling antislavery tract from its publication in 1839 until the appearance of Uncle Tom's Cabin in 1852. The two works inaugurated a series of pamphlets and books with such telltale titles as Scenes of Oppression in the Refined Circles of the South and Picture of Slavery in the United States of America, tracts that gained great popularity with their intended audience of white northerners. ${ }^{8}$

To combat skeptics' dismissal of American Slavery As It Is, Weld sought to establish his narratives through scrupulous standards of proof. The importance of firsthand testimony was twofold: it avoided hearsay and fulfilled the evangelical desire to hear of things close to the heart. In the evangelical framework, the measure of authenticity lay in the feelings, not the intellect; the most striking oral and written testimony was the eyewitness account, which put the reader as close as possible to the slave's pain. As Robert Abzug suggests, through such testimony, audiences could "witness the sin of slavery as it acted in men's consciences; they could watch the process by which heartfelt recognition of sin would . . emancipate both master and slave." Those following in Weld's footsteps bravely proclaimed the fidelity of their material; it was a high point in any meeting when, for example, in discussing a slave reputedly crippled when she fell from a window as she was trying to escape a master's beating, a member could contribute that he had seen the woman in question, and that one of her arms was noticeably crooked.?

Cruelty narratives did not stake out the moral high ground, and many abolitionists preferred to argue that slavery was a matter, not of treatment, but of principle. But the stories' very offensiveness was riveting, and they proved to be among the most effective and dramatic weapons in the reform arsenal: speakers often righteously denied any intention to "harrow up" an audience's feelings before going on to dwell enthusiastically on atrocities. ${ }^{10}$ Weld and the Grimkés among others realized that sensationalism was effective: in compiling American Slavery As It Is, they sent out a long circular asking for information on "PUNISHMENTS - please

${ }^{8}$ Lydia Maria Child, An Appeal in Favor of That Class of Americans Called Africans (Boston, 1833), 6; Theodore Dwight Weld, American Slavery As It Is: Testimony of a Thousand Witnesses (1839; New York, 1968); Gilbert Hobbs Barnes, The Antislavery Impulse, 1830-1844 (1933; Gloucester, Mass., 1957), 264n20, 276n5, 73; Mrs. M. B. Davis, Scenes of Oppression in the Refined Circles of the South, Addressed to the Women of Illinois (Peoria, 1846); George Bourne, Picture of Slavery in the United States of America (1834; Detroit, 1972). Lydia Maria Child's Appeal actually mixed several genres of argument; see Jean Fagan Yellin, Women and Sisters: The Antislavery Feminists in American Culture (New Haven, 1989), 54-55.

${ }^{9}$ Abzug, Passionate Liberator, 90; Proceedings of the New-England Anti-Slavery Convention . . 1834 (Boston, 1834), 26. During an incredulous discussion of Eliza's escape across the ice floes in Uncle Tom's Cabin, a man at an 1852 convention piped up, "It is true; I knew the man who helped her out of the river." The Annual Report of the American and Foreign Anti-Slavery Society . . . 1852 (New York, 1852), 27.

${ }^{10}$ Proceedings of the Anti-Slavery Convention of American Women . . . 1837 (New York, 1837), 7; Abzug, Passionate Liberator, 132-35. After such a disclaimer, a New Hampshire convention devoted the next fifteen pages to atrocities; Proceedings of the N.H. Anti-Slavery Convention Held in Concord. . . 1834 (Concord, 1834), $16-30$. 
describe in detail the different modes, postures, instruments and forms of torture. ... Facts and testimonies are troops, weapons and victory, all in one." Some, like Theodore Parker, took as a matter of principle that disdain for the slave's person and physical sufferings impeded the recognition of his humanity, and they insisted that, far from being incidental to the system, cruelty was its bone and sinew: "The relation of master and slave begins in violence; it must be sustained by violence - the systematic violence of general laws, or the irregular violence of individual caprice." 11

Tales of abuse remained an effective hook for the public right up until the Civil War. Five Hundred Thousand Strokes for Freedom, for example, published in London in 1853 using many American sources, is a compilation of over eighty tracts "calculated to increase a feeling of sympathy for that [enslaved] portion of suffering humanity." They bore such titles as Slave Branding, Murder of an Infant, and Hunting Slaves with Blood Hounds. ${ }^{12}$

After 1840 the trope of the suffering slave emerged in a new genre, autobiographical accounts by freed or escaped slaves. The 1840 s was a decade of growing international acclaim for slave narratives. The best known went through many editions in the northern United States and in Europe: Moses Roper's account went to ten editions and was translated into Celtic, and over one hundred thousand copies of Josiah Henson's story were sold. Such demand created a market in which "almost any victim of slavery could get published," and by the end of the Civil War over one hundred ex-slaves had. Abolitionists, often involved as scribes, agents, editors, or distributors of the slave accounts, understood the value of these accounts from their days on the lecture circuit, where the firsthand testimony of former slaves about their lives in the South had proven the biggest draw. ${ }^{13}$

William Andrews suggests that most practitioners of the slave narrative in its classic form, who wrote between 1840 and 1860 , set out to portray slavery as a brutalizing institution designed to annihilate the slave's very self. The trickster was largely absent from these stories, in which slaves were reduced to helpless objects of cruelty and exploitation. All made the point, openly or tacitly, that cruelty was inherent in the system of slavery. While each account differed in its own obscene particulars, there were formulaic scenes: the whipping or mutilation of family members and of the narrator; the auction block where slaves had to perform to demonstrate their value and where they were separated from other members of their families, most for the last time; and the transportation of slaves in coffles, or chain gangs. Frederick Douglass's famous narrative establishes the slave system as one of

${ }^{11}$ Gilbert H. Barnes and Dwight L. Dumond, eds., Letters of Theodore Dwight Weld, Angelina Grimke Weld, and Sarah Grimke, 1822-1844 (2 vols., New York, 1934), II, 809. For Theodore Parker's statement, see Lynd, Intellectual Origins, 139. See also Abolitionist, 1 (no. 5, 1833), 69; and American Anti-Slavery Almanac, 1 (no. $2,1837), 33-34$.

${ }^{12} \mathrm{~A}$ second printing of this compilation was issued after the first one-half million copies sold out. Wilson Armistead, ed., Five Hundred Thousand Strokes for Freedom (1853; Miami, 1969), esp. "Preface," [p. 3].

${ }^{13}$ Charles H. Nichols, Many Thousand Gone: The Ex-Slaves' Account of Their Bondage and Freedom (Leiden, Netherlands, 1963), xi-xvi, esp. xiv; Barnes and Dumond, eds., Letters of Weld, Grimke, and Grimke, II, 811; James B. Stewart, Holy Warriors: The Abolitionists and American Slavery (New York, 1976), 137-38. 


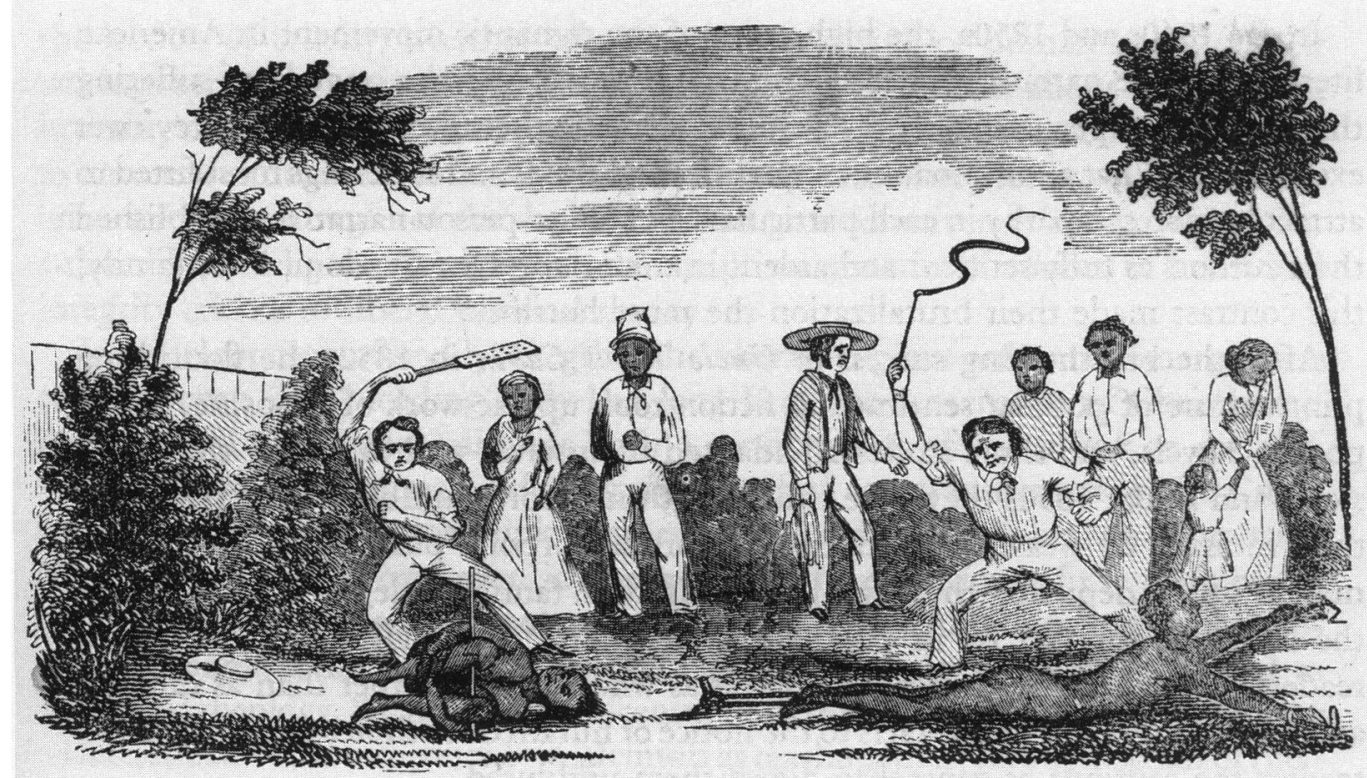

Flogging staked slaves, from Henry Bibb, Narrative of the Life and Adventures of Henry Bibb, An American Slave, Written by Himself (New York, 1849), 132.

Courtesy Boston Athenaeum.

unremitting savagery; one short chapter includes four unprovoked murders. Others, for example, John Brown, described practices such as "bucking," during which slaves were flogged until bloody and then washed with a mixture of salt, red pepper, and water. By midcentury, slave narrators competed with each other to produce ever more sensational effects, using such titles as Life and Narrative of William J. Anderson, Twenty-Four Years a Slave; Sold Eight Times! In Jail Sixty Times! Whipped Three Hundred Times!!! Andrews finds that post-Civil War slave accounts, in contrast, stressed the strength and endurance of Blacks under slavery. The change suggests that the writers believed that in antebellum culture, the depiction of suffering had strategic value. ${ }^{14}$

14 William L. Andrews, "The Representation of Slavery and the Rise of Afro-American Literary Realism, 18651920," in Slavery and the Literary Imagination, ed. Deborah E. McDowell and Amold Rampersad (Baltimore, 1989), 62-80, esp. 62-66; Frederick Douglass, Narrative of the Life of Frederick Douglass, An American Slave, Written By Himself(1845; New York, 1968), 38-42; John Brown, Slave Life in Georgia: A Narrative of the Life, Sufferings, and Escape of John Brown, A Fugitive Slave, ed. F. N. Boney (1855; Savannah, 1972), 35; William L. Andrews, To Tell a Free Story: The First Century of A fro-American Autobiograpby, 1760-1865 (Urbana, 1986), 184-86. But William Andrews points out that in the 1850s some slave narrators began to stress their own acts of retaliation rather than their passive suffering; Andrews, "Representation of Slavery," 62-66. 
In the 1840 s and 1850 s, the high point of the romantic movement in American literature, these narratives offered intimate glimpses into the tragedy of suffering that were more persuasive than reformers' didactic rhetoric: one ecstatic reviewer exclaimed, "What a combination of qualities and deeds and sufferings most fitted to attract human sympathy in each particular case!" First-person narratives established their authors as fully sentient and ardent in their desires for freedom, love, family; this contrast made their brutalization the more horrific. ${ }^{15}$

After the breathtaking success of Uncle Tom's Cabin in 1852, the flourishing print culture of popular sentimental fiction took up the work of exposure. Plays, poems, novels, and short stories all adapted themselves well to telling the slave's story, and in the 1850 s they were churned out in record numbers. Most tempered their message by weaving descriptions of brutal corporal punishment into sentimental stories depicting the lowly but loving slave family circle, its intimates, and the suffering entailed by its poignant destruction. ${ }^{16}$ Fictional accounts engaged readers' sympathies by fleshing out slaves as whole people rather than as cameos, and they brought the sordid facts to the notice of hundreds of thousands of northern readers too cautious or genteel to digest them undiluted.

By the Civil War, then, the account of slave suffering designed to evoke a sympathetic response had established itself as an important social and cultural trope in the North. It was not just repetition that gave these stories their impact. Rather, they drew on and confirmed a major shift in religious sensibility, as American Protestants, influenced by the liberalization of doctrine, were revising their understanding of the purpose and place of suffering in human life.

\section{"I Sing the Body Anesthetic"}

While both the theological and the humanitarian roots of the revulsion from cruelty lie in the eighteenth century and earlier, the modern sensibility that we associate with the legal protection of dependent classes flourished more fully in the nineteenth century. In this period another profound transformation was underway, the erosion of Calvinist orthodoxy and the emergence of a powerful alternative often labeled liberal Protestantism. One result was the reorientation of the relationship between religion and the body. In the antebellum era, liberal Unitarian clergy, shock troops in the assault on Calvinism, forged a Christian humanist philosophy that rejected

\footnotetext{
${ }^{15}$ Charles T. Davis and Henry Louis Gates Jr., eds., The Slave's Narrative (New York, 1985), 19. Andrews interprets the slave narrator as revisionist, in Harold Bloom's definition, a writer who "wishes to open received texts to his own sufferings." So Frederick Douglass made his own experiences a yardstick against which to measure and reinterpret the Bible and the Declaration of Independence: See Andrews, To Tell a Free Story, 13-14.

${ }^{16}$ Philip Fisher, Hard Facts: Setting and Form in the American Novel (New York, 1985), 101-4. For an extensive bibliography, see Lorenzo Dow Turner, Anti-Slavery Sentiment in American Literature Prior to 1865 (1929; Port Washington, 1966), 89-100.
} 
the notion of cruelty, whether administered by divine or human hand. ${ }^{17}$ Their writings served as a primary source for abolitionist arguments about the inherent brutality of slavery. They also provided abolitionists with a new model for a claim to universal entitlement to bodily integrity, one that stood opposed to much diversitarian scientific thought of the day and helped ground universal human rights. For a time liberal religious thought became the primary carrier of notions of individual integrity critical to liberal political theory.

In its celebration of bodily integrity, the liberal religious order that emerged was revolutionary. The bleeding body had long been the centerpiece of Christianity; for medieval Christians, pain was both a confirmation of and a link to divinity. The inevitability of human suffering was glorified and transfigured in the Crucifixion, which forged a strong link between pain and divinity. Voluntary submission to pain contained its own grim joy, as witnessed by depictions of the trials of the saints. Protestant Reformers took most of the joy out of suffering, but they maintained predestination, limited salvation, and original sin as doctrines central to Reformed theology. Such nineteenth-century reformers as William Ellery Channing characterized - and caricatured - Calvinism as teaching that, through no fall of their own, a substantial portion of mankind was "made liable to all miseries in this life, to death itself, and to. . . . 'most grievous torments in soul and body without intermission in hell-fire forever." 18

Liberal religionists in the antebellum era rejected this harsh creed. They shifted their focus from the drama of God, the sovereign judge, sentencing the inherently depraved human to an afterlife of unremitting suffering, to that of God, the benevolent father, working for his children's physical and spiritual well-being. The purpose of worship shifted from the glorification of God to the salvation and celebration of man. ${ }^{19}$ This optimistic new theology included a celebration of the human body, that work of God "fearfully and wonderfully made." As Theodore Parker summed up this ethos, "the great work of mankind on earth is to . . use, discipline, develop, and enjoy every limb of the body, every faculty of the spirit." 20

The evolution of the doctrine of Atonement, or Christ's death as the guarantor of human salvation, typified shifting attitudes toward pain and punishment across

\footnotetext{
${ }^{17}$ Daniel Walker Howe, The Unitarian Conscience: Harvard Moral Philosophy, 1805-1861 (Cambridge, Mass., 1970). For radical Unitarians who addressed themselves explicitly to social problems, see, for example, Donald Yacovone, Samuel Joseph May and the Dilemmas of the Liberal Persuasion, 1797-1871 (Philadelphia, 1991); Theodore Parker, The Slave Power, ed. James K. Hosmer (Boston, [1910]); and Theodore Parker, The Rights of Man in America, ed. F. B. Sanborn (Boston, 1911).

${ }^{18}$ David B. Morris, The Culture of Pain (Berkeley, 1991), 125-27; William E. Channing, "The Moral Argument Against Calvinism," in William E. Channing, The Works of William E. Channing, D.D., Eighth Complete Edition, with an Introduction (6 vols., Boston, 1848), I, 217-41, esp. 223; Ava Chamberlain, "The Theology of Cruelty: A New Look at the Rise of Arminianism in Eighteenth-Century New England," Harvard Theological Review, 85 (July 1992), 335-56.

${ }^{19}$ William E. Channing, "Unitarian Christianity: Discourse at the Ordination of the Rev. Jared Sparks," in Channing, Works, III, 59-103, esp. 83-87; H. Shelton Smith, Changing Conceptions of Original Sin (1955; New York, 1987), 60-85; Jay Fliegelman, Prodigals and Pilgrims: The American Revolution against Patriarchal Authority, 1750-1800 (Cambridge, Eng., 1982), 155-94.

${ }^{20}$ [George Allen], Mr. Allen's Report of a Declaration of Sentiments on Slavery, December 5, 1837 (Worcester, 1838), 6; Theodore Parker, Ten Sermons of Religion (New York, 1864), 4.
} 
a wide spectrum of Protestant denominations, not just those formally labeled "liberal." By the late eighteenth century, Congregational ministers within the New Divinity movement urged that God ordained the Passion, not from a self-serving desire for retribution, but "from the most noble benevolence and regard to the public good." They concurred that Christ had probably not suffered real pain, or at least not in full human measure. By the nineteenth century, most Protestants, despite differences across and even within denominations, had come to share a tender-minded distaste for the extravagant agony of the Passion. ${ }^{21}$ Some in the liberal wing, Quakers and Unitarians, altogether rejected the efficacy of the Crucifixion in effecting human salvation, discarding what had stood for nearly two millennia as the central theological construct of Christianity and the most profound link between God and man. ${ }^{22}$

The transition from a punitive to a benevolent God advanced the reinterpretation of human pain, and the antislavery movement drew heavily on this new reading. Unavoidable suffering, such as sickness, remained an inevitable part of human experience, but liberal theology severed the link between punitive or deliberately inflicted pain and religious experience and downgraded the role of suffering in moral growth. The rejection of avoidable or intentionally caused suffering was not just a by-product of the movement against religious or thodoxy, but one of its main goals. Nineteenth-century reformers indicted orthodox Calvinism as incorporating the most terrible and prolonged suffering into the heart of its philosophy. Parker told an archetypal story of the grim imprint of a Calvinist childhood, recounting fearful hours spent in frigid churches contemplating the inevitable descent into the fires of hell. ${ }^{23}$

Although in their own philosophy liberal clerics integrated the experiences of body and soul, they juxtaposed the two in a way that ran radically counter to the medieval Christian model. There, the tension arose from the shocking opposition of the free soul to its racked body - the smiling Saint Sebastian full of arrows. For nineteenth-century liberals, however, the tension arose from the presence of pain itself, which signaled, not spiritual triumph, but a breach of divinely ordained laws. Liberal religionists embraced a model of natural religion that sought God's will in the workings of the natural world rather than in scriptural revelation. From

${ }^{21}$ Jonathan Edwards [Jr.], "Three Sermons," in The Atonement. Discourses and Treatises, ed. Edwards A. Park (Boston, 1859), 1-42, esp. 36; Frank Hugh Foster, A Genetic History of the New England Theology (Chicago, 1907); Dorus Paul Rudisill, The Doctrine of the Atonement in Jonathan Edwards and His Successors (New York, 1971). For a critique of this doctrinal shift as a decline into sentimentalism, see Douglas, Feminization of American Culture, 143-96.

${ }^{22}$ Howe, Unitarian Conscience, 42, 98; Bliss Forbush, Elias Hicks: Quaker Liberal (New York, 1956), 200; Elias Hicks, Letters (New York, 1834), 67, 127-28; Jerome Hall, "Biblical Atonement and Modern Criminal Law," Journal of Law and Religion, 1 (no. 2, 1983), 279-95.

${ }^{23}$ Albert Barnes, The Atonement In Its Relations to Law and Moral Government (Philadelphia, 1860), 24042; James Freeman Clarke, Orthodoxy: Its Truths and Errors (1866; Boston, 1926), 252-54; John Weiss, Life and Correspondence of Theodore Parker (2 vols., London, 1863), I, 30; Chamberlain, "Theology of Cruelty." On the persistent power of the Christlike image of the suffering slave, see Walters, Antislavery Appeal, 57-59; Jane Tompkins, Sensational Designs: The Cultural Work of American Fiction, 1790-1860 (New York, 1985), $122-46$. 
their emphasis on the harmonious interactions in the natural realm, they inferred that the states of the body and soul were congruent, whether in pain or pleasure. God in his benevolence had so laid out the physical world that those who obeyed his laws would prosper. Only those who flouted the laws of human nature courted misfortune; and their suffering was the spontaneous consequence of their lawbreaking, rather than the punitive revenge of a sovereign God. ${ }^{24}$

The conviction that God's will could be read in the structure of the natural world relocated the sources of religious authority and, potentially, those of political authority. Interpreting pain as flowing from the breach of a natural law moved it from the realm of normal human experience and toward the status of an anomaly. A body in pain - particularly pain deliberately inflicted by another - became compelling evidence of human transgression; thus, a policy or system built on governance by pain could impugn the legitimacy of the government sponsoring it. For many abolitionists, the enormity and seeming randomness of eternal damnation came to epitomize the arbitrary abuse of sovereign power, and their revulsion against it fueled their participation in humanitarian reforms. ${ }^{25}$

While the role of pain in religious thought was being transformed, its medical significance was undergoing a swift revision. In a convenient sleight of hand, the medical profession assumed epistemological responsibility for pain just as it dropped out as an underpinning of theology. In the early nineteenth century, doctors began characterizing pain as a treatable pathology rather than as divine punishment or common biological medium; this was most dramatically marked by the first use of anesthesia at Massachusetts General Hospital in 1846. The reassignment of physical agony as a medical or therapeutic problem offered a comprehensive alternative explanation to those seeking to discard it from their theology and bolstered abolitionist attempts to set pain outside the common realm of human interaction. ${ }^{26}$

In other respects, however, abolitionists were moving against the scientific tide in their attempts to portray slaves' pain as real. "Scientific" arguments for the inferiority of Blacks had plagued the antislavery movement for years. Well before the writings of Charles Darwin, the entrenched popular theory of the Great Chain of Being set out a hierarchy of creation. Departing from the Linnaean classification of "species," the theory divided humans into ranked groups on the basis of physical type. Among humans, those of African descent ranked low on the scale, only just

${ }^{24}$ Barnes and Dumond, eds., Letters of Weld, Grimke, and Grimke, I, 491; Martin S. Pernick, A Calculus of Suffering: Pain, Professionalism, and Anesthesia in Nineteenth-Century America (New York, 1985), 48-49. For natural religion's place in Unitarianism, see Howe, Unitarian Conscience, 69-92.

${ }^{25}$ Milton Meltzer and Patricia G. Holland, eds., Lydia Maria Child, Selected Letters, 1817-1880 (Amherst, 1982), 335; Silvan Tomkins, "The Psychology of Commitment: The Constructive Role of Violence and Suffering for the Individual and for His Society," in The Antislavery Vanguard: New Essays on the Abolitionists, ed. Martin Duberman (Princeton, 1965), 270-98; Elaine Scarry, The Body in Pain: The Making and Unmaking of the World (New York, 1985).

${ }^{26}$ Pernick, Calculus of Suffering; Judith Walzer Leavitt, Brought to Bed: Childbearing in America, 17501950 (New York, 1986), 116-41. 
above the highest animals. Defenders of slavery often invoked the almost subhuman status of African Americans. ${ }^{27}$

This theory of the dominant and subordinate standings of different races contributed to the belief, widely held in the nineteenth century, that racial groups differed in their physiological responses to pain. According to the popular hierarchy of sensibility, women, whites, and the rich ranked as the most sensitive to pain. Equally predictably, people of African descent were classed together with criminals and Indians as virtually impervious to physical trauma, a trait one Louisiana physician labeled as "a peculiar instinct protecting it against the abuses of arbitrary power." "Research" by southern doctors also discovered a disease hereditary in the line of African descent called "dyaesthesia Aethiopsis," an "obtuse sensibility of body" that reportedly made its victims insensitive to the effects of corporal punishment. One researcher carefully noted his surprise when, upon his pouring boiling water down the spine of a slave, the patient leaped up in agony. ${ }^{28}$

Against this backdrop, the reiterations in antislavery literature of the agony experienced by slaves during whippings and other punishments took on a revolutionary quality. Such depictions were designed to rouse northern consciences lulled by the myth that Black Americans experienced abuse differently. Many northerners may have considered deliberately inflicted pain taboo. But to push for protection they had to believe that the slave had "the same susceptibilities of suffering . . . inherent in the constitutions of all animals. ... [that] his body suffers from hunger and thirst, cold and nakedness, imprisonment and corporal punishment, hard labor and want of rest." The portrayal of a slave's pain proved the likeness of the human body across racial lines; as an abolitionist, Miss Smith, wrote of seeing a slave beaten by a mob, "I am ready to testify that it was orthodox blood. I should not have known it from my own." Advocates courted the outrage of their listeners by telling stories of masters treating slaves as if they were animals, particularly tales of the use and chastisement of slaves' bodies. The anarchist provocateur Parker Pillsbury reportedly made that point by going through the rite of baptism with a dog, forcing the fuming spectators to examine their own presumptions about who was a fit recipient of the sacraments and who was not. ${ }^{29}$

The antebellum campaign to establish slaves as fully sentient beings with Godgiven physical sensibilities provided a refurbished vehicle for a philosophy of universalism - and so potentially for universal entitlement - at a time when Enlightenment

\footnotetext{
${ }^{27}$ James Turner, Reckoning with the Beast: Animals, Pain, and Humanity in the Victorian Mind (Baltimore, 1980), 7; Winthrop D. Jordan, White over Black: American Attitudes toward the Negro, 1550-1812 (Baltimore, 1969), 216-65; James M. McPherson, "A Brief for Equality: The Abolitionist Reply to the Racist Myth, 18601865," in Antislavery Vanguard, ed. Duberman, 156-77.

${ }^{28}$ Pernick, Calculus of Suffering, 155-56; Todd Savitt, "The Use of Blacks for Medical Experimentation and Demonstration in the Old South," Journal of Southern History, 48 (Aug. 1982), 331-48.

${ }^{29}$ Angelina Grimké, "Slavery is Cruel to the Body, Heart, Mind, and Soul of the Slave," typescript, n.d., box 19, Weld-Grimké Papers (William Clements Library, University of Michigan, Ann Arbor); Report of a Delegate to the Antislavery Convention of A merican Women Held in Philadelphia, May, 1838 (Boston, 1838), 15; Proceedings of the American Anti-Slavery Society At Its Second Decade (1854; Westport, 1970), 69; Parker Pillsbury, Acts of the Anti-Slavery Apostles (1883; Miami, 1969), 49-51.
} 
thought, which had helped check any tendency to exaggerate human difference in the early years of the Republic, had lost much of its force. In doing so, it went against both popular thought and a growing body of scientific work whose focus on physical differences among races threatened to destroy the intellectual basis of the argument for universal human rights. ${ }^{30}$ Antislavery workers, drawing on the ascendant liberal religious teachings, kept the competing ideal of universal rights alive in the tradition of Christian equalitarianism. They relied heavily on religious arguments to make the slave's case, mixing them with natural rights theory in a way that made the two perfectly compatible. Emphasizing Christian humanist notions of the value of each life, they asserted that Christianity rejected all distinctions of superiority and inferiority among races or classes of humankind: to set slaves apart was a form of atheism, a retreat from the "common table of humanity." 31

But while Enlightenment universalism was rooted in a belief in standard, specieswide typologies, antebellum universalism was of necessity more complex. The language of standardization did not sit well in a culture becoming attuned to romantic notions of the depth and diversity of human experience, rather than its interchangeability. In the case of slavery, it was the intensely individual experience of suffering - experienced by the highborn and lowborn alike - and its demand for attention that conferred equality. Abolitionists charged northerners with "hypocrisy" because they "oozed sympathy" for Europe's suffering hordes while ignoring slaves. The demand for equal treatment presupposed that all sufferers are similarly situated and deserving of sympathetic relief. In the 1830s the universal duty of benevolent sympathy to the show of suffering took over where an Enlightened belief in uniformity left off. ${ }^{32}$

\section{Sympathy, Sensibility, and Revivalism}

Within religious thought, it was the liberal Protestant denominations, in particular, Unitarianism, that championed the new celebration of the integrity of the body. But the liberalizing trend toward the benevolent, unpunishing God also touched all but the most crabbed of orthodox Calvinists, establishing a common ground from which reformers could condemn cruelty and preparing a Christian audience receptive to their criticism.

${ }^{30}$ George M. Fredrickson, The Black Image in the White Mind: The Debate on Afro-American Character and Destiny, 1817-1914 (Middletown, 1971), 71-96; James M. McPherson, The Struggle for Equality: Abolitionists and the Negro in the Civil War and Reconstruction (Princeton, 1964), 134-53; and William R. Stanton, The Leopard's Spots: Scientific Attitudes toward Race in America, 1815-59 (Chicago, 1960).

${ }^{31}$ Susan C. Cabot, "What Have We, As Individuals, To Do With Slavery," in Antislavery Tracts (1855-1856; Westport, 1970), no. 15, p. 6; William Goodell, The Democracy of Christianity; or, An Analysis of the Bible and its Doctrines in their Relation to the Principle of Democracy (2 vols., New York, 1849), I, [13]-19; Jordan, White over Black, 293.

${ }^{32}$ Liberty Bell (Boston, 1847), 36-37; Arthur O. Lovejoy, The Great Chain of Being: A Study of the History of an Idea (Cambridge, Mass., 1966), 227-41. 
Similarly, evangelical religious practice made popular a style of moral reasoning from sympathy and compassion that was best developed in the revival churches, but that was also a familiar and comfortable mode for liberal religionists. Liberal Unitarians feared the excesses of enthusiasm displayed at the rowdier revival meetings and repeated at antislavery meetings. But their rationalism - particularly among those most opposed to slavery - accommodated the moral and religious sentiments as beneficial in their appropriate place. Within abolitionism the duty to sympathize with slaves was not a tenet limited to the evangelical party. William Lloyd Garrison kept a figure of a kneeling slave on his mantelpiece "to keep my sympathies from flagging." Channing stressed that people should not "turn away from the contemplation of human sufferings. . . . It is meant to call forth deep sympathy with human nature." ${ }^{33}$ Thus, sympathy-a term that in the nineteenth century encompassed empathy as well - became a common construct across a wide spectrum of antislavery thetoric. In antebellum thought, sympathy was a complex process in which the observer's willed attentiveness to another's suffering gave rise to an intuitive empathic identification with the other's experiences. The habit of sympathy was a part of many Christians' religious practice, a habit that abolitionists drew on in their presentation of the suffering of slaves.

The rise of a sympathetic or affective mode of moral reasoning is an overdetermined phenomenon, appearing first in English religious thought and literature. In moral philosophy, the tradition of ethical sentimentalism launched by Anthony Ashley Cooper, third earl of Shaftesbury, made familiar the notion that a moral sense enabled individuals to judge an act according to their own subjective responses. Shaftesbury's ideal of the moral sense, elaborated by such followers as Francis Hutcheson and Adam Smith, aided in the transition from the belief that morality was revealed in the Scriptures to the notion that it was best studied in the innate intuitions and sentiments of humankind. ${ }^{34}$

In America, evangelicalism became the popular locus for the affective style; the conversion experience offered an immediate, personal connection with God forged in moments of heightened emotional sensibility. The first Great A wakening of the 1740 s had challenged the cold, dry legalism of orthodoxy with an appeal to an affective style of religious experience. The stress on a warmer bond with God also

${ }^{33}$ Liberator, Feb. 22, 1834, p. 31; William E. Channing, "Slavery," in Works, II, 5-153, esp. 58, 123-28. On the relationship between rational and affective modes of religious experience within Unitarianism, see Howe, Unitarian Conscience, 151-73; and Levi Blodgett [Theodore Parker], The Previous Question Between Mr. Andrews Norton and His Alumni Moved and Handled in a Letter to All Those Gentlemen by Levi Blodgett(Boston, 1840), 11-13. For the inner light as an alternative to rational forms of religious experience within Quakerism, see Dana Greene, ed., Lucretia Mott: Her Complete Speeches and Sermons (New York, 1980), 235-51, 349-58; and H. Larry Ingle, Quakers in Conflict: The Hicksite Reformation (Knoxville, 1986), 41-45, 66-67, 82-83.

${ }^{34}$ R. S. Crane, "Suggestions toward a Genealogy of the 'Man of Feeling," ELH, 1 (Dec. 1934), 205-30; John K. Sheriff, The Good-Natured Man: The Evolution of a Moral Ideal, 1660-1800 (University, Ala., 1982); John Mullan, Sentiment and Sociability: The Language of Feeling in the Eighteenth Century (New York, 1988); William E. Alderman, "Shaftesbury and the Doctrine of Moral Sense in the Eighteenth Century," PMLA, 46 (Dec. 1931), 1087-94. Ethical sentimentalism was an early source of antislavery thought; see David Brion Davis, "What the Abolitionists Were up Against," in Antislavery Debate, ed. Bender, 17-26, esp. 22-23. 
offered a new paradigm for interpersonal relationships. By the late eighteenth century, James Essig suggests, the benevolent Christian "entered into a sympathetic relationship with other individuals and thereby multiplied the sources of emotional gratification." Many envisioned "the good society as a network of benevolent believers, united by ties of sentiment, their hearts quivering with affectionate regard for the well-being of others." Inspired by this new association of Christian benevolence with sympathy for others, certain evangelical groups in the last quarter of the century turned their "tender feelings" toward the first brief movement against slavery. ${ }^{35}$

Thirty years later, the Second Great Awakening served as an important backdrop for a variety of antebellum reforms. Evangelicalism continued to privilege feelings over intellect and to repudiate the doctrinal formalism of seventeenth- and eighteenth-century Protestantism as a loveless exercise, "all hic haec hoc and no God in it." The move toward a religion of the heart was a critical step away from the hard "system" of Calvinism, and the revival meeting with its public prayer and testimony created a community of intense feeling. By the 1830s, then, many Americans turned for guidance to the emotions over the intellect, identifying the moral sense more with feeling than with rational thought. ${ }^{36}$

The revival of passionate antislavery organization in the early 1830 s followed directly on the heels of the great wave of revivalism inaugurated by Charles Finney in the 1820s, and it tracked the forms of revivalism closely. ${ }^{37}$ Many early abolitionists, particularly those in the New York circle of the brothers Arthur and Lewis Tappan, had been in training for the ministry and were deeply influenced by revivalism, and by Finney in particular. Some took up abolition as a sacred vocation in the aftermath of the student debates at Lane Seminary in Cincinnati in 1834, and they drew a strong analogy between the suddenness of conversion and the immediate emancipation they sought for the slave. ${ }^{38}$

${ }^{35}$ Essig, Bonds of Wickedness, 38, 40-41. The other important influence on the affective tradition was pietism; see David S. Lovejoy, Religious Enthusiasm in the New World: Heresy to Revolution (Cambridge, Mass., 1985); and William G. McLoughlin, "Pietism and the American Character," American Quarterly, 17 (Summer 1965), 163-86.

${ }^{36}$ Barnes and Dumond, eds., Letters of Weld, Grimke, and Grimke, I, 45, 142-43; Charles C. Cole Jr., The Social Ideas of the Northern Evangelists, 1826-1860 (1954; New York, 1977), 79-80; Sandra S. Sizer, Gospel Hymns and Social Religion: The Rhetoric of Nineteenth-Century Revivalism (Philadelphia, 1978), 50-82. The revolution of feeling reached the highest levels when in 1856 a Miss Plummer endowed a Harvard chair for "a professorship of the heart, not the head." Walters, Antislavery Appeal, 61.

${ }^{37}$ Leonard I. Sweet, "The Evangelical Tradition in America," in The Evangelical Tradition in America, ed. Leonard I. Sweet (Macon, 1984), 1-86, esp. 16-19. The Weld-Tappan wing of abolitionism, which operated along the New York-Oberlin axis, was most closely associated with evangelicalism: See Barnes, Antislavery Impulse; Anne C. Loveland, "Evangelicalism and 'Immediate Emancipation' in American Antislavery Thought," Journal of Soutbern History, 32 (May 1966), 172-88; and David Brion Davis, "The Emergence of Immediatism in British and American Antislavery Thought," Mississippi Valley Historical Review, 49(Sept. 1962), 209-30. Clearly, though, revivalism alone did not account for the resurgence of the antislavery movement, since even the most revivalistic denominations did not formally espouse antislavery views: John R. McKivigan, The War against Proslavery Religion: Abolitionism and the Nortbern Churches, 1830-1865 (Ithaca, 1984); Drew Gilpin Faust, "Evangelicalism and the Meaning of the Proslavery Argument: The Reverend Thornton Stringfellow of Virginia," Virginia Magazine of History and Biography, 85 (Jan. 1977), 3-17.

${ }^{38}$ Donald M. Scott, "Antislavery as a Sacred Vocation," in Antislavery Reconsidered: New Perspectives on the Abolitionists, ed. Lewis Perry and Michael Fellman (Baton Rouge, 1979), 51-74, esp. 59; Lawrence Thomas Lesick, The Lane Rebels: Evangelicalism and Antislavery in Antebellum America (Metuchen, 1980); Bertram Wyatt-Brown, "Conscience and Career: Young Abolitionists and Missionaries," in Anti-Slavery, Religion, and 
The force of the abolitionists' appeal to sympathy for the slave was directly bound up with the career of revivalism and derived much of its power from the same source. Finney and his brethren perfected techniques for stirring crowds to an emotional pitch as a preliminary to a conversion experience. Antislavery agents schooled themselves in similar tactics, describing their role as kindling, warming, "combustionizing" their listeners. Using intense feeling as the touchstone for authentic spiritual experience, their greatest measure of success - frequently achieved - was that they had left "not . . . a dry eye" in the house. ${ }^{39}$

Revivalism's style of reaching the crowd provided a close model for abolitionists' attempts to awaken a compassionate response in their own audiences, for by the Second Great Awakening, evangelicalism had embraced moral sympathy, in a form that owed much to its eighteenth-century Scottish forebear. While the idea of moral sympathy can be traced through Shaftesbury, Hutcheson, and David Hume, it was most fully developed in an early work by Adam Smith, The Theory of Moral Sentiments. Designed to combat the Hobbesian notion that human nature is basically self-interested, it also addressed the problem of civil governance in a world of romantic individuals: How can we create binding, universal legal and political conventions when we have so little understanding of the interior emotions and needs of others? For Smith, sympathy - the willed act of knowing a fellow being was the answer.

By the imagination we place ourselves in his situation, we conceive ourselves enduring all the same torments, we enter as it were into his body, and become in some measure the same person with him. . . His agonies . . when we have thus adopted and made them our own, begin at last to affect us, and we then tremble and shudder at the thought of what he feels. ${ }^{40}$

Only through this act of imagination was it possible to grasp the subjective experience of another well enough to understand his needs; for "the man whose sympathy keeps time to my grief, cannot but admit the reasonableness of my sorrow." Sympathy, then, allowed individuals to act in the social and political spheres in a benevolent way that acknowledged the needs and passions of others. ${ }^{41}$

Reform: Essays in Memory of Roger Anstey, ed. Christine Bolt and Seymour Drescher (Hamden, Conn., 1980), 183-203.

${ }^{39}$ Barnes and Dumond, eds., Letters of Weld, Grimke, and Grimke, I, 338. See also ibid., I, 49n1, 143, 220, II, 564; Gerda Lerner, The Grimke Sisters from South Carolina: Rebels Against Slavery (Boston, 1967), 142; Lesick, Lane Rebels, 82-84. There was a strong cultural discontinuity between the Founders and the abolitionists; it is hard to imagine James Madison or Thomas Jefferson congratulating themselves on having left "not a dry eye" in the audience. Unitarian preaching also moved toward a more spontaneous and evocative style at the same time: See Howe, Unitarian Conscience, 160-72.

${ }^{40}$ Adam Smith, The Theory of Moral Sentiments, ed. D. D. Raphael and A. L. Macfie (1759; Indianapolis, 1982), 9. The book was reprinted in Boston, New York, and Philadelphia in 1817, 1821, 1822, and 1876, and in Boston and New York in 1887. Key figures in early nineteenth-century moral philosophy continued to teach the importance of sympathy: Thomas Reid, The Works of Thomas Reid (4 vols., Charlestown, 1815), IV, 99-100; Dugald Stewart, ed., Essays on Philosophical Subjects by the Late Adam Smith (Dublin, 1795), xlviii, 275. On the influence of Scottish philosophy, see Henry F. May, The Enlightenment in America (New York, 1976), 34250; and Meyer, Instructed Conscience, 35-42.

${ }^{41}$ Smith, Theory of Moral Sentiments, 16; Nicholas Phillipson, "Adam Smith as Civic Moralist," in Wealth and Virtue: The Shaping of Political Economy in the Scottish Enlightenment, ed. Istvan Hont and Michael Ignatieff 
Evangelicals agreed on the beneficial effects of sympathy: as one minister said of his congregants, "Never do they love one another so well as when they witness the outpouring of each other's hearts in prayer," assuming that to witness another's strong emotion was to enter into it..$^{42}$ But sympathy represented praxis, not theory. Evangelicals did not believe the sympathetic response to be automatic or involuntary. As Finney preached, we should "command our attention" to certain things, and by so doing "emotions will come up, by the very laws of mind." Evangelicals preached a duty to turn one's mind to things that would evoke moral sympathy. To do so was to use one "means" at the individual's disposal to prepare to accept God's grace; to refuse to "dwell on things calculated to excite warm and overpowering feelings" showed a deficiency in the Christian spirit. ${ }^{43}$

Crusading members of the American Anti-Slavery Society in the 1830s solicited audiences with a religious model of sympathetic conversion in mind. Like revivalists, abolitionists preached a duty to exhort, to "recite the tale of woe in the ear of your children, family, friends and neighbors, to enkindle a similar feeling in them." As Theodore Weld cautioned Angelina Grimké Weld about their young son: "I rejoice that you are taking pains to cultivate little Charleys sympathy and compassion by showing him the poor slaves in the hold of the slave ship. Pray do it often constantly. The only way effectually to cultivate those elements in the mind of a child is to show them suffering objects." Abolitionists themselves practiced sympathy conscientiously, as if it were an exercise. John Rankin tutored his compassion by picturing his family as slaves being whipped; but as his "imagination depicted in lively colors, their tears, their shrieks, and bloody stripes," he found himself too agitated to go on. ${ }^{44}$ Tracts and speeches instructed readers and listeners to imagine that they were being whipped or to imagine that their children were standing on the auction block.

Such exercises depended on and fostered strong identification with the slave's presumed response. For Elizabeth Margaret Chandler, for example, the key to emancipation was compassion; and the key to compassion was "mental metempsychosis." Were northerners to "imagine themselves for a few moments in [the slave's] very circumstances, to enter into his feelings, comprehend all his wretchedness, transform

(New York, 1983), 181-91. For Jean-Jacques Rousseau's related construction of sympathy and compassion, which would have been familiar to some American readers in this period as well, see David Marshall, The Surprising Effects of Sympathy: Marivaux, Diderot, Rousseau, and Mary Sbelley (Chicago, 1988), 135-77; and Fisher, Hard Facts, 105 .

${ }^{42}$ Charles G. Finney, Lectures on Revivals of Religion (New York, 1835), 114, 59-60; William B. Sprague, Lectures on Revivals of Religion (Albany, 1832), 106-8; Robert Baird, Religion in America (New York, 1844), 208-9. Again showing interdenominational cross-pollination, Daniel Walker Howe points out the place of moral sentiments within Unitarian rationalism: Howe, Unitarian Conscience, 52, 58-64. See also [Theodore Parker], West Roxbury Sermons by Theodore Parker, 1837-1848 (Boston, 1902), 58.

${ }^{43}$ Finney, Lectures on Revivals of Religion, 34, 82. On sympathy as a duty, see John Radner, "The Art of Sympathy in Eighteenth-Century British Moral Thought," Studies in Eighteenth-Century Culture, 9 (East Lansing, 1979), 189-210.

${ }^{44}$ Proceedings of the N.H. Anti-Slavery Convention Held in Concord . . . 1834, 31; Barnes and Dumond, eds., Letters of Weld, Grimke, and Grimke, II, 892; Rankin, Letters on American Slavery, 56. 
themselves mentally into his very self, they would not surely long withhold their compassion." 45

Like Smith's work on moral sentiments, abolitionist literature suggested that the effort to observe and enter into another's feelings served as a foundation of social life: sympathy was both a "powerful principle which binds man to his fellow" and a call to action. The slave owner understands his white peers; "with them he identifies himself, and towards them the sympathies of his nature . . . are exercised"; sympathy allows them to create a polity. His inability to identify with slaves, though, meant that he could not regard them as "allied to him by any relation calling for sympathy . . . . [although] it is over this latter race that he possesses power"-hence the failure to extend "justice, benevolence, and charity" to the slave. ${ }^{46}$

In addition to laying the groundwork for the appeal to moral sympathy, evangelical revivalism also provided a model for abolitionists by its innovation in pulpit storytelling. Eighteenth-century sermons rarely used anecdotes drawn from secular life, relying instead on biblical parables to illustrate doctrinal points. By 1800 a new style of preaching had come into vogue: anecdotal rather than doctrinal, it embraced the moral value of human experience. Finney was the most prominent exponent of pulpit storytelling; like many religious thinkers influenced by Scottish common sense philosophy, he saw the natural world and human life as a source for instructional material. He argued that the preacher's diction should be conversational, his illustrations drawn from the common business of society. He encouraged would-be revivalists to approach their stories as an actor would, who resolves to

throw himself into the spirit and meaning of the writer, as to adopt his sentiments, make them his own, feel them, embody them, throw them out upon the audience as living reality. . . . And if by "theatrical" be meant the strongest possible representation of the sentiments expressed, then the more theatrical a sermon is, the better. ${ }^{47}$

For the well-told story provided the audience with a cathartic experience; through a fully realized rendition of another's spiritual sufferings, the listener's own heart would often be changed. The fact that, on Sundays, Christians were edified from the pulpit by stories of individuals like themselves in distress probably predisposed them to listen to abolitionists' anecdotes with a more practiced ear.

Abolitionist writers and lecturers were ingenious in their use of sources that aroused sympathy and compassion. Southern newspapers provided a steady supply of ads for runaways with grotesque scars, mangled limbs, missing members, and

\footnotetext{
${ }^{45}$ Elizabeth Margaret Chandler, Essays, Philanthropic and Moral (Philadelphia, 1836), 117; Walters, Antislavery Appeal, 57; Proceedings of the American Anti-Slavery Society At Its Second Decade, 44, 51-52.

${ }^{46}$ Baird, Religion in America, 209; Quarterly Anti-Slavery Magazine, 1 (July 1836), 317. Opponents of the rhetoric of sympathy feared its power; see [Isaac Taylor], Natural History of Enthusiasm (New York, 1834), 910; and Meltzer and Holland, eds., Lydia Maria Child, Selected Letters, 326n2.

47 Finney, Lectures on Revivals of Religion, 204, 192-95; Albert Barnes, Miscellaneous Essays and Reviews (2 vols., New York, 1855), II, 82-86; David S. Reynolds, "From Doctrine to Narrative: The Rise of Pulpit Storytelling in America," American Quarterly, 32 (Winter 1980), 479-98.
} 
other deformities inflicted under slavery. Another favorite technique was the publication of excerpts from southern legal codes, showing the lenient fine levied on any individual who should "wilfully cut out the tongue, put out the eye, castrate, or cruelly scald, burn or deprive any slave of any limb or member" - and then only if the tormentor were convicted..$^{48}$

Abolitionists noted that visual images also stirred readers, and they took advantage of the new importance of visual culture. The image of the enchained or abused slave became a cultural icon and made its way into music and popular fiction and onto knickknacks and souvenirs. Songs and stories such as "The Bereaved Slave," "O Pity the Poor Slave Mother," and "The Little Blind Slave Boy" passed lightly over the gory details while playing on themes of suffering and sympathy familiar to readers of sentimental literature. The store owned by the well-known abolitionist Tappan brothers sold prints depicting "The Poor Slave" in four different poses, as well as "'handsome' plaster manikins of slaves in chains for only fifty cents apiece." Mite boxes, handkerchiefs, and other paraphernalia distributed by the American Anti-Slavery Society bore the familiar image of the kneeling slave. At a meeting of female reformers, Sarah Grimké moved that such pictorial representations be increased a hundredfold, so that the "speechless agony of the fettered slave may unceasingly appeal to the heart of the patriot, the philanthropist, and the christian."49

Abolitionists also strove to make their language as vivid as possible, fostering in audiences the feeling that a direct line of physical sensation linked them to the slave. Readers and listeners could then judge the morality of slavery by their own subjective responses to the physical and moral degradation inherent in the system. While some antislavery fiction played solely on the genteel sentimental themes well known to readers of midcentury popular literature, such writers as Child, Weld, and George Bourne did not scruple to use graphic, vivid language of a kind then thought unsuitable for polite society. Elizabeth Margaret Chandler described the northern dinner table with its use of slave-harvested sugar as a scene of gothic horror: "I have fancied that the death-sigh of some unfortunate victim of oppression might be yet trembling on the bosom of a jelly . . . A pound cake seems like the sepulchre of the broken heart with which it may, perhaps, have been purchased, and the delicious ice to wear the red tinge of human blood." Chandler, the first writer to make a direct empathic appeal through her columns in the Genius of Universal Emancipation, denied that she was catering to "a display of benevolent feeling, or the indulgence of an amiable humanity." Such lines as "Amid her weeping babes she knelt, and o'er her crouching head/The white man's lash in mockery swung, all newly stain'd with red" make a shocking parody of the family grouping so familiar from sentimental literature. Ralph Waldo Emerson affirmed

${ }^{48}$ L. Maria Child, The Patriarchal Institution, As Described By Members of Its Own Family (New York, 1860), 10-16; George M. Stroud, A Sketch of the Laws Relating to Slavery in the Several States of the United States of America (Philadelphia, 1856), 25.

${ }^{49}$ Anti-Slavery Songs From the Best Anti-Slavery Authors (Salem, Ohio, 1849); Wyatt-Brown, Lewis Tappan, 155, 143; Proceedings of the Anti-Slavery Convention of American Women . . 1837, 14; Yellin, Women and Sisters. 
the strong effects created by images of old men and pregnant women being whipped: "The blood is moral: the blood is anti-slavery: it runs cold in the veins: the stomach rises with disgust, and curses slavery." 50

To create an immediate experience, abolitionist writing sometimes adopted a stylized first-person voice to describe a slave's experience. More commonly, it drew liberally from published or unpublished slave narratives. Testimony from a former Louisiana resident used a different technique to describe a whipping:

The blood flows, the long wounds cross each other, strips of skin are raised without softening . . . the hand of the executioner. . . The reader is moved; so am I: my agitated hand refuses to trace the bloody picture, to recount how many times the piercing cry of pain has interrupted my silent occupations.

This passage creates an extraordinary physical economy between master, slave, narrator, and reader: the ruthlessness of the master's hand causes the writer's hand to tremble; the slave's cry becomes noise in the writer's quiet room; the reader is moved as well. Another of the witnesses in American Slavery As It Is reported in a narrative on slave catching that he had recently been bitten by a dog used to hunt slaves; the reader can all but feel the teeth. ${ }^{51}$

The imagery of the chain took on a complex set of meanings in this period. In the most obvious sense, the falling away of real or spiritual chains signaled a new life for those in bondage to sin and slavery both. But the chain had positive connotations as well. Resonance and reverberation through a chain provided a physical metaphor that captured the essence of sympathy: one link vibrates and its near neighbor quivers in response. Using a similar construction, contemporary scientific thought concluded that the imagination, working through the body's nervous system, "allowed our distress to create in another person sensations of sympathy that link us together in a chain of feeling." " 22 central trope in evangelical antislavery rhetoric, the chain represented an imagery with powerful social implications at odds with a liberal model of autonomous individualism.

Women made particular contributions to the social model of the sympathetic response. The generic story of the male slave whipped touched a chord with audiences, but few men were likely to find themselves in similar situations. All mothers, though, slave and free, understood danger to their children; the store of harrowing maternal fears could accommodate multiple unlikely variations. Tracts and essays sought to rouse maternal instincts in defense of slave women and children. Mothers

${ }^{50}$ Chandler, Essays, 87, 28; Elizabeth Margaret Chandler, The Poetical Works of Elizabeth Margaret Chandler (Philadelphia, 1836), 63; R. W. Emerson, Address Delivered in the Courthouse in Concord, Massachusetts on 1st August, 1844, on the Anniversary of the Emancipation of the Negroes in the British West Indies (Boston, 1844), 6; John Ashworth, "The Relationship between Capitalism and Humanitarianism," in Antislavery Debate, ed. Bender.

${ }^{51}$ Weld, American Slavery As It Is, 59, 15. On the "staggering number of slave interviews, autobiographies, and letters" in abolitionist periodical literature, see John Blassingame, The Slave Community: Plantation Life in the Antebellum South (New York, 1979), 378.

52 Essig, Bonds of Wickedness, 40-41. On scientific ideas about sympathy, see Morris, Culture of Pain, 207; and Walter Jackson Bate, From Classic to Romantic: Premises of Taste in Eigbteenth-Century England (New York, 1946), 100. 


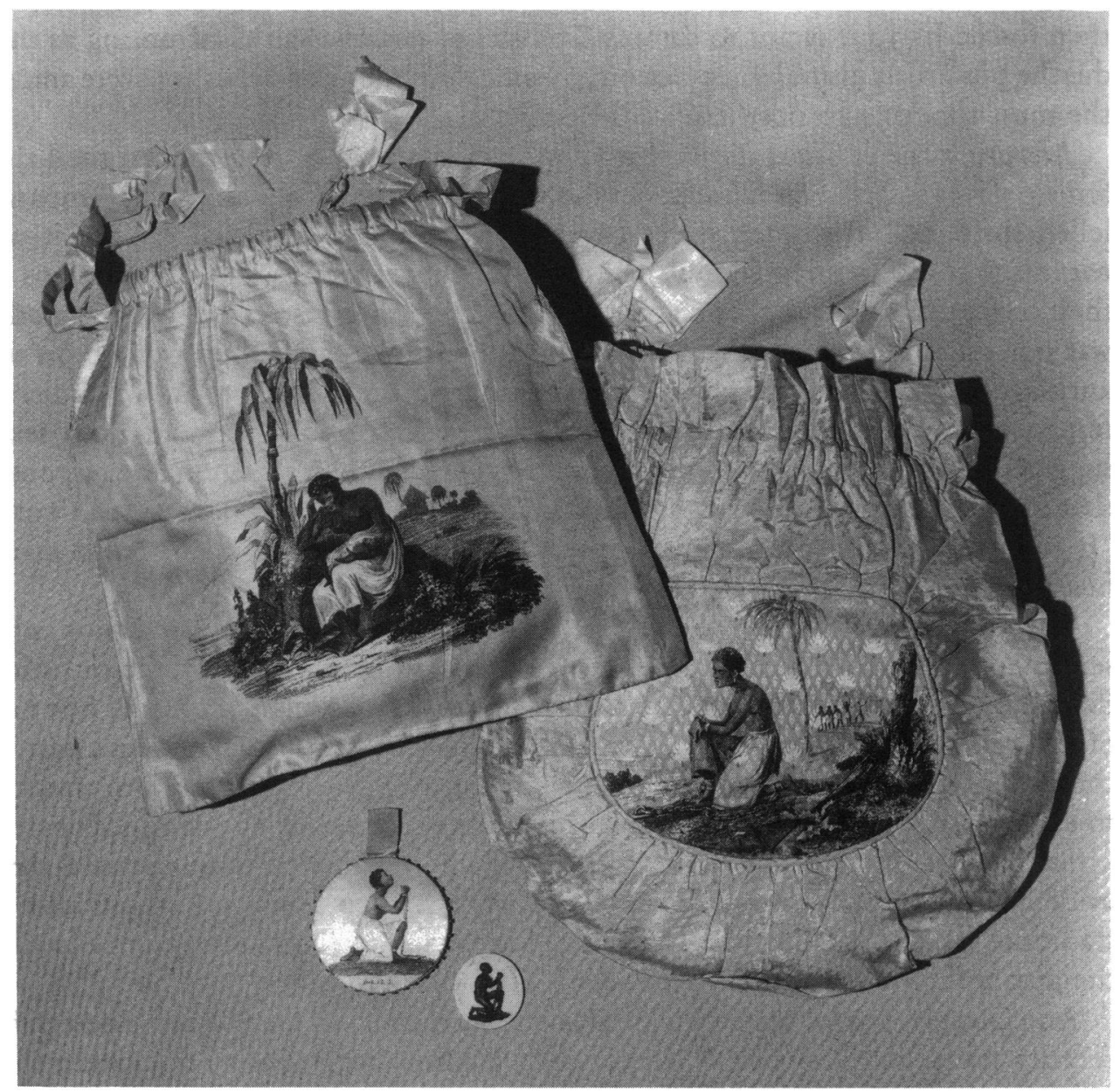

Two silk drawstring bags, a pinholder, and a cameo medallion, depicting slaves (1820-1830). Courtesy the Daughters of the American Revolution Museum, Gift of Mrs. Erwin L. Broecker.

who failed to make the connection were admonished point-blank to imagine the sale or murder of their own children..$^{33}$

Narratives of masters' lecherous assaults also exploited audiences'-particularly women's - fear of uncontrolled sexuality. In an era that celebrated the gentle, docile natures of women and children, sexual or physical violence directed at them seemed especially repugnant. It was no great trick for the women who pioneered the concept of "voluntary motherhood" to obey abolitionist exhortations to "fancy yourselves every moment liable to be polluted - and, if you refuse submission, to be lacerated, 
then forced by your tyrant to comply." Stories of sexual assault, affronting as they did the powerful cultural construction of women's modesty and chastity, were among the most shocking to northern audiences. ${ }^{54}$

Adopting the cultural trope of women's defenselessness, reformers argued that female slaves suffered far more under the violent regime than males. This "unparallelled suffering" of women slaves gave rise to claims to a special calling: it was natural that "all women should feel most for the sufferings and degradations of their own sex," and that they should wish to act on their sisters' behalf. Sympathy was not the exclusive province of women: the Grimkés and other women on the antislavery circuit adapted the tactics of evangelical revivalism to incite audience response, much as their male counterparts did. But abolitionists of both sexes suggested that, for women, sympathy was less a willed than an automatic response, that sympathetic interaction was women's natural métier. What was women's work? "It is to sympathize with human misery. It is to breathe sympathy into man's heart." "ss

The vogue of sympathy had a broader currency through its association with sentimental literature, a genre closely connected to women writers. Domestic fiction flourished on the crest of the expansion of the publishing industry in the first half of the nineteenth century. While antislavery novels constituted just one part of the total output, women's sentimental fiction routinely relied on appeals to emotion to evoke pity for the weak and distressed, leading the reader to "compassionate," across barriers of status and race, with those whose suffering demonstrated their evident humanity. Women reformers and writers, then, drew on an established tradition, but they pioneered new cultural forms that were instrumental in allowing the attribution of sentience - particularly the ability to suffer - to slaves. ${ }^{56}$

Ann Douglas has suggested that sentimentalism replaced theology in nineteenthcentury religious experience. ${ }^{57}$ This is only partially true, but to the extent that religious teaching centering on the interpretation of doctrine gave way to "pulpit storytelling" or the use of narrative texts, readers and listeners had greater latitude

${ }^{54}$ [George Bourne], Slavery Illustrated in Its Effects Upon Woman and Domestic Society (1837; Freeport, N.Y., 1972), 126; Ronald G. Walters, "The Erotic South: Civilization and Sexuality in American Abolitionism," American Quarterly, 25 (May 1973), 177-201; Ashworth, "Relationship between Capitalism and Humanitarianism," 180-99, esp. 197; Karen Sanchez-Eppler, Touching Liberty: Abolition, Feminism, and the Politics of the Body (Berkeley, 1993), 21-23, 32-41.

"Liberator, July 27, 1838, p. 117; [Maria Weston Chapman], Ninth Annual Report of the Boston Female Anti-Slavery Society . . 1842 (Boston, 1842), 26; [Maria Weston Chapman], Right and Wrong in Boston: Report of the Boston Female Anti-Slavery Society . . . 1835 (Boston, 1836), 87. On the possible link between women's perceived weakness and the genre of sentimental literature, see Nina Baym, Woman's Fiction: A Guide to Novels by and about Women in America, 1820-70 (Urbana, 1993), xxxv-xlii.

${ }_{56}$ On women publishing, see Mary Kelley, Private Woman, Public Stage: Literary Domesticity in NineteenthCentury America (New York, 1984), esp. 6-12; and Susan Coultrap-McQuin, Doing Literary Business: American Women Writers in the Nineteenth Century (Chapel Hill, 1990). Abolitionist periodicals such as the Genius of Universal Emancipation and the Liberator had "ladies departments" that regularly published sentimental poems and sketches focusing on the plight of slaves: Sanchez-Eppler, Touching Liberty, 23-32. On sentimentalism and the appeal to emotion, see Elizabeth White, "Sentimental Heresies: Rethinking The Feminization of American Culture," Intellectual History Newsletter, 15 (Boston, 1993), 23-31; Fisher, Hard Facts, 118-22; Baym, Woman's Fiction, xx, xxvii-xxxii.

${ }^{57}$ Douglas, Feminization of American Culture, 143-96. 


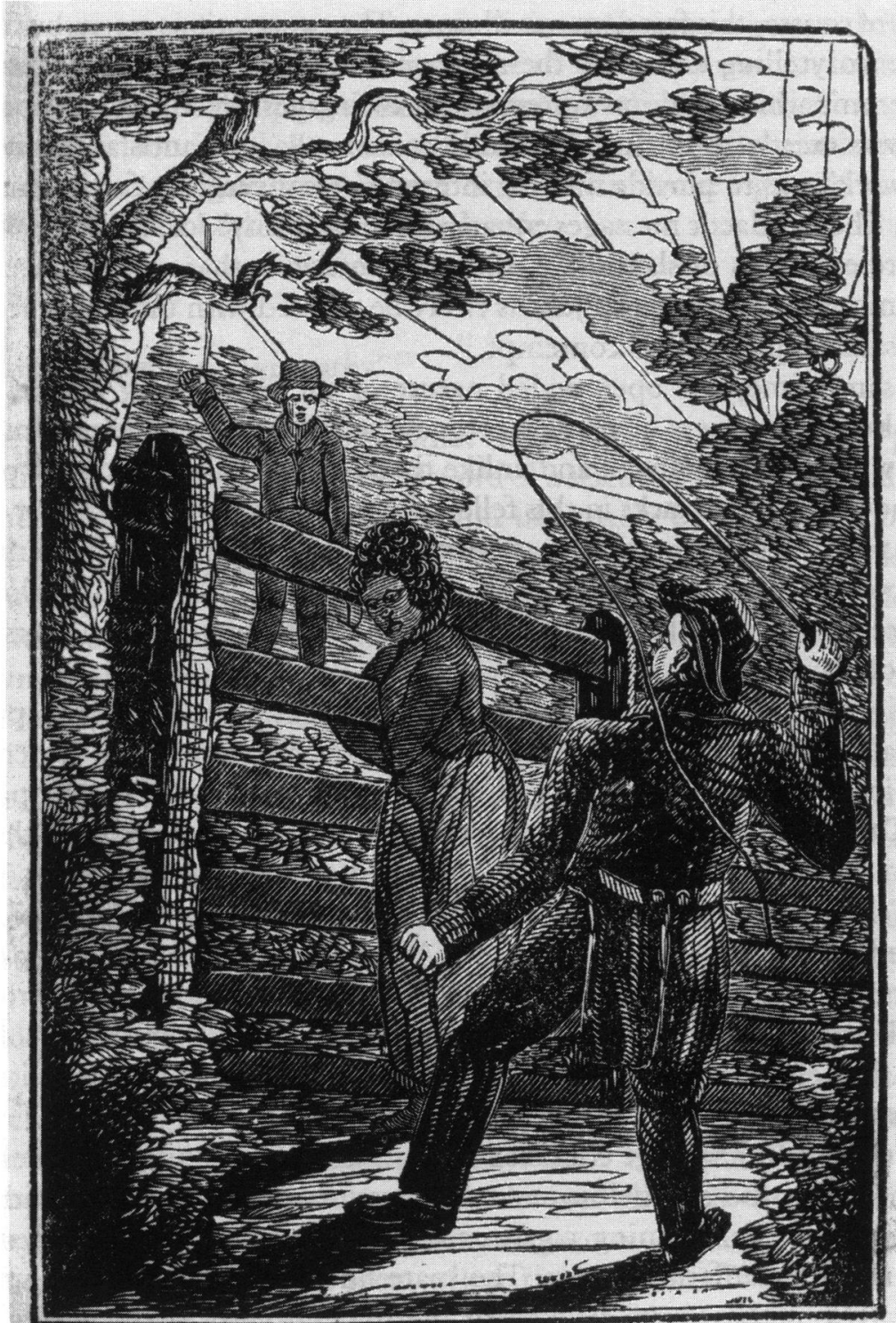

Flogging American Women. Page 100.

Whipping a slave woman, from George Bourne, Picture of Slavery in the United States of America (Middletown, 1834), 105. Courtesy Boston Athenaeum.

for interpretation. Similarly, both abolitionist narrative accounts and sentimental fiction dwelling on the "poor slave" sought to evoke a subjective emotional reaction that seemingly allowed each audience member to respond from the heart in his or her own fashion. 
In part, of course, this freedom was illusory. The expectations set up by formulaic or didactic storytelling enhanced the message that all right-feeling people should experience empathic revulsion on exposure to images of cruelty, although that revulsion was exactly the cultural attitude at issue. Part of antislavery literature's "cultural work" was to provide a set of interpretive conventions for its images and anecdotes. These didactic messages enhanced the "stability" (or, fixed the meaning) of the representations of slaves in pain, representations that, in the absence of a strong normative context, could just as easily be greeted with unsympathetic emotions like sadistic pleasure or contempt. ${ }^{58}$

At the same time, the open-ended nature of the storytelling format allowed large numbers of listeners or readers to imagine themselves in joint sympathetic enterprise with their neighbors; and unlike theology or politics, narrative presentations did not expose the cracks in this fellow feeling by forcing debate over concrete tenets. In part for this reason, the movement of the trope of the suffering slave from the political realm of abolitionism into popular literary culture allowed the convergence of much northern public opinion in condemnation of masters' violent discipline of slaves. ${ }^{59}$

In this light, Nina Baym sees sentimentalism "not as evasive self-absorption but as a practical philosophy of community" based on "public sympathy and benevolent fellow-feeling." Domestic literature offered the perfect exercise in sympathy; its reader, as Dugald Stewart had earlier suggested, follows "in imagination, the unfortunate man to his dwelling, and partakes with him and his family in their domestic distresses." The home was revealed as the site of entry into private spaces and feelings that sparked the sympathetic imagination. An abolitionist exhorted, "look at [the slave's] person. . . . Follow [the slaves] next to their huts . . . see them groaning." For antebellum reformers, as for Smith and his followers, the "communion of feeling and sympathy" created a benevolent order between strangers that substituted for defective legal and political arrangements. ${ }^{60}$

Historians have by and large criticized or dismissed abolitionists' arguments from empathy. ${ }^{61}$ But in the antebellum era, compassionate identification with others played a positive role, forming conduits for arguments about the extension of individual rights to suffering others. The spare liberal notion of bodily autonomy made its way into the courts cloaked in sentimental garb. Sympathy was often identified as a womanly trait, and women's transforming role in abolitionism, reviv-

58 Tompkins, Sensational Designs, 124-27; Scarry, Body in Pain, 13-14. For narratives of suffering as they shape arguments for legal redress, see Kathryn Abrams, "Hearing the Call of Stories," California Law Review, 79 (July 1991), 971-1052.

\$9 Brodhead, Cultures of Letters, 13-47.

${ }^{60}$ Baym, Woman's Fiction, xxix-xxx; Dugald Stewart, Elements of the Philosophy of the Human Mind (Boston, 1821), 272; Weld, American Slavery As It Is, 16-17; Liberator, Feb. 25, 1837, p. 33. For the pitfalls of northern women's overidentification with enslaved women, see Yellin, Women and Sisters, 78-79.

${ }^{61} \mathrm{See}$, for example, Eric Foner, "Abolitionism and the Labor Movement in Antebellum America," in AntiSlavery, Religion, and Reform, ed. Bolt and Drescher, 254-71; and Aileen S. Kraditor, Means and Ends in American Abolitionism: Garrison and His Critics on Strategy and Tactics, 1834-1850 (New York, 1969), $243-44$. 
alism, and sentimental literature-important sites of compassionate rhetoric-is well documented. At the same time, the vogue of sympathy was not contained or captured by any discrete grouping defined by gender, theology, or reform faction. Precisely because it flourished at so many different points within the culture, fellow feeling for those in pain gave new scope to arguments for the rights of the person that were innovative in both substance and style.

\section{"The Surprising Effects of Sympathy" ${ }^{2}$}

Antislavery rights discourse was a lay, rather than a legal, tradition, fluid precisely because it did not depend on the revealed word of a statute or constitutional amendment; it included broader claims than would ultimately be recognized by courts or legislatures. But its repugnance to slavery's personalized violence and its claims of self-ownership and bodily autonomy for slaves struck a note that would persist in the evolution of individual rights consciousness. David Brion Davis has described abolitionism as emblematic of "a new system that redefined rewards, punishment, and the kind of undeserved 'suffering' that ought to arouse the sympathy of strangers." The moral conventions produced by that new order were not transcendent or absolute, and often not victorious in the human arena; nonetheless, over time they have become incorporated as a persistent strand in our rights tradition. ${ }^{63}$

In the eighteenth century, the individual's quota of rights as laid out by the Declaration of Independence and the Constitution enabled him to vote, to speak, to own property, to enjoy the protection of the legal system, and to participate in public life. Nineteenth-century abolitionists expanded on these entitlements to claim in addition "rights" more in keeping with a vision of human nature that stressed the individual's sentient experience. Indeed, at times abolitionist rhetoric based the claim to rights on the very capacity to suffer and feel pain-what one slave narrator called "the sacred rights of the weak." Frederick Douglass phrased it more concisely: "If he knows enough to be hanged, he knows enough to vote." Out of this formulation grew a novel vision of government as obliged to provide special safeguards for the downtrodden, whose rights claims, Channing suggested, were "enhanced, on the ground that the suffering and injured are entitled to peculiar regard." 64

${ }^{62}$ This is a phrase of the French playwright Pierre de Marivaux, adopted by Marshall, Surprising Effects of Sympathy, 9.

${ }_{63}$ Davis, "Perils of Doing History," 294; Hartog, "Constitution of Aspiration." Rights did not take their preeminent place in American constitutional history until after the Civil War. See Morton Keller, "Powers and Rights: Two Centuries of American Constitutionalism," Journal of American History, 74 (Dec. 1987), 675-94. For a compelling essay on the growth of human rights conventions, see Thomas L. Haskell, "The Curious Persistence of Rights Talk in the "Age of Interpretation," ibid., 984-1012.

${ }_{64}$ Andrews, "Representation of Slavery," 68; Proceedings of the American Anti-Slavery Society At Its Third Decade ... 1863 (1864; New York, 1969), 114; William E. Channing, "Duty of the Free States," in Channing, Works, VI, 231-373, esp. 243; Sanchez-Eppler, Touching Liberty, 1-49. 
Despite their violent quarrels, abolitionists from all factions concurred that the right of self-ownership was a precondition to the enjoyment of other rights, and that all slaves should immediately be credited with "a fee simple in their own blood, bones, and brains." Taken by itself, the phrase self-ownership did not reveal its component parts. But abolitionists consistently enumerated a category of natural rights derived from the physical wants and needs of the body on its daily rounds. Four claims in particular stand out: the right to freedom of movement; the right to marry and establish domestic relations; the right of a female slave to refuse sexual relations with white men; and the right of a slave to be free of physical abuse or coercion imposed by masters or other quasi officials without due process of lawa "right to be exempted from coercion, stripes, and punishment, as long as he respects the rights of others." 65

In extending an ethos of nonviolent punishment from state action to private relationships, the antislavery movement both drew on and fed the objections to the use of corporal punishment that had crescendoed in the antebellum era. The use of physical chastisement in prisons and mental hospitals, on naval ships, in schoolrooms, and even by parents came under attack by reformers who urged that physical punishment be used only as a last resort, and only in moderation. Wife abuse rose to visibility as a public problem, with many states expanding the grounds for divorce to include cruelty. Even cruelty to animals became less respectable, at least among the genteel: several editions of the famous weepy Black Beauty carried the subtitle, The "Uncle Tom's Cabin" of the Horse. ${ }^{66}$

What these movements had in common is a rejection not just of cruelty between sentient beings, but of cruelty in relationships of power. As Judith Shklar notes, cruelty as a vice appeared late on the Western scene, roughly coincident with the

${ }^{65}$ Liberator, March 17, 1837, p. 46; William Hosmer, Slavery and the Church (1853; New York, 1969), 185. To contrast eighteenth-century definitions of natural rights, see Daniel T. Rodgers, Contested Truths: Keywords in American Politics since Independence (New York, 1987), 49-51. On the right to freedom of movement, see Liberator, June 6, 1835, p. 89; Jacobus tenBroek, Equal under Law (1951; New York, 1965), 87-88, 125; and William Hosmer, The Higher Law in Its Relation to Civil Government (1852; New York, 1969), 88-89. On the right to marry, see tenBroek, Equal under Law, 53, 123-25; Channing, "Slavery," 35; Liberator, Oct. 31, 1835, p. 173 ; and ibid., Feb. 13,1836 , p. 25 . On the right to refuse sexual relations, see Proceedings of the American Anti-Slavery Society At Its Second Decade, 44; Sarah Grimké, "Letters on the Equality of the Sexes and the Condition of Woman," in The Public Years of Sarah and Angelina Grimke: Selected Writings, 1835-1839, ed. Larry Ceplair (New York, 1989), 207-10; and Proceedings of the Ill. Anti-Slavery Convention Held at Upper Alton . . 1837 (Alton, Ill., 1838), 15. Finally, on the right to be free of physical abuse, see Channing, "Slavery," 35, 17; Lerner, Grimke Sisters, 114; and tenBroek, Equal under Law, 51-54.

${ }^{66}$ Brodhead, Cultures of Letters, 13-47; Myra C. Glenn, Campaigns Against Corporal Punishment: Prisoners, Sailors, Women, and Children in Antebellum America (Albany, 1984); Philip Greven, The Protestant Temperament: Patterns of Child-Rearing, Religious Experience, and the Self in Early America (New York, 1977), 27681; Gerald N. Grob, Mental Institutions in America: Social Policy to 1875 (New York, 1973); Elizabeth Pleck, Domestic Tyranny: The Making of Social Policy against Family Violence from Colonial Times to the Present (New York, 1987), 34-66; Robert L. Griswold, "Law, Sex, Cruelty, and Divorce in Victorian America, 1840-1900," American Quarterly, 38 (Winter 1986), 721-45; Turner, Reckoning with the Beast; Anna Sewell, Black Beauty: The "Uncle Tom's Cabin" of the Horse (Boston, 1894). On the related issue of pacifism in this period, see Lewis Perry, Radical Abolitionism: Anarchy and the Government of God in Antislavery Thought (Ithaca, 1973); and Peter Brock, Radical Pacifists in Antebellum America (Princeton, 1968). 

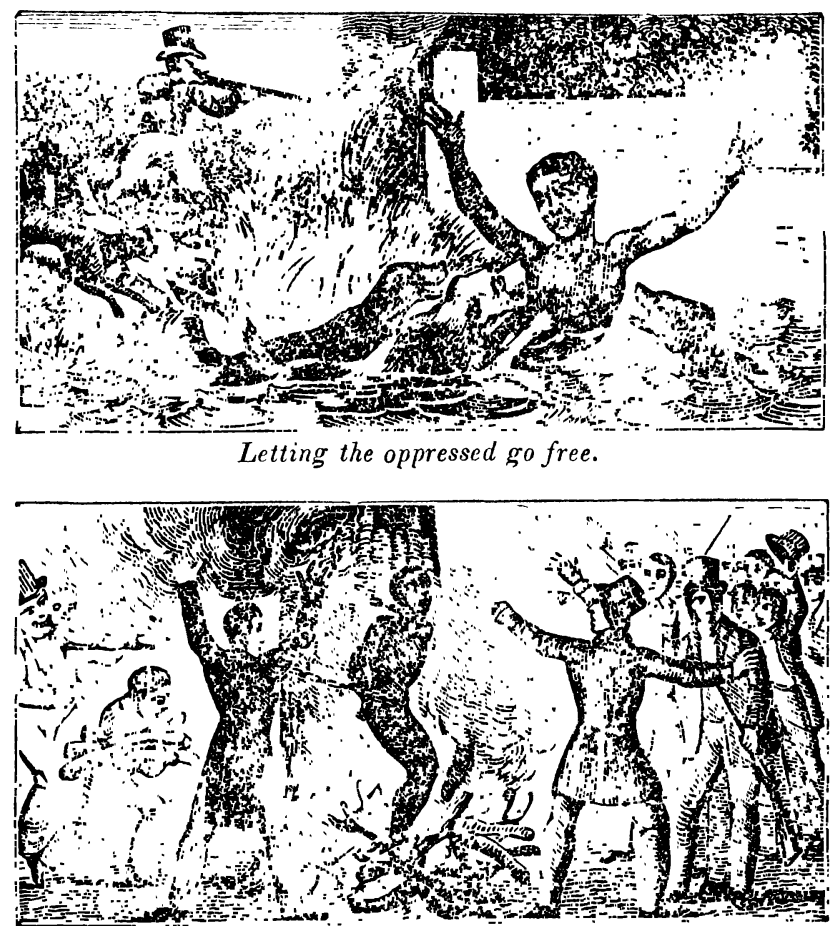

Southern Court of Law and Equity.

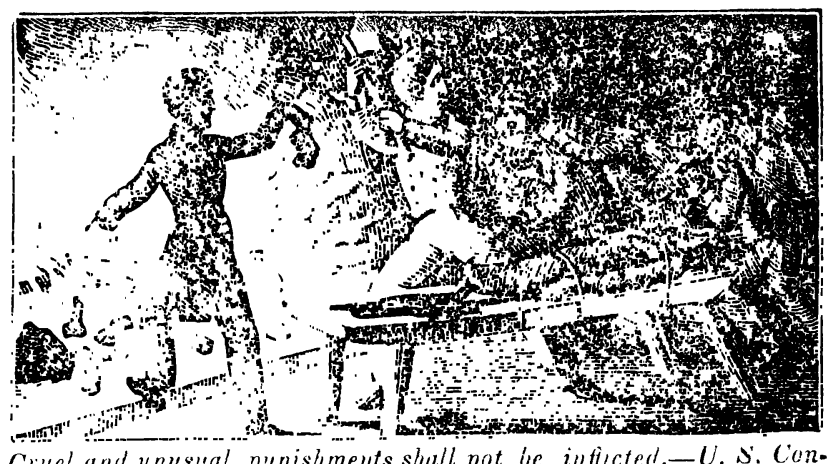

Depictions of southern "justice" link the abuse of slaves to concerns about bodily integrity, self-ownership, and individual rights. Reprinted from

The Legion of Liberty and Force of Truth (New York, 1857), 166. Courtesy Boston Athenaeum.

appearance of a newly benevolent God. By the eighteenth century, though, "putting cruelty first" among vices became a powerful underpinning of liberal democracy. Enlightened opinion set its face decidedly against deliberate infliction of extreme 
punishments by the civil state, as reflected in the constitutional ban on cruel and unusual punishments in the United States. ${ }^{67}$ While the critique of excessive power in the state was the signature of eighteenth-century political theory, antebellum reformers' trademark was the extension of that critique to "private" status relations, including the master-slave, husband-wife, and parent-child pairings, in which the common law had invested private citizens with quasi-governmental powers over dependent others, such that public and private ordering overlapped substantially. Plantation "justice" outraged the same sensibilities that condemned torture, excessive sentences, and public punishments and executions by the state. ${ }^{68}$ Bringing stories of abuse into public view was an early attempt to rationalize status relationships and to delegitimize the unbridled personal power of masters over slaves, which the party of reform considered barbaric. Individual rights claims posed a critical challenge to such power.

The Civil War and Reconstruction reoriented reformers, away from popular rights discourse and toward faith in a legal positivist vision of rights and remedies as secured by statute or constitutional amendment. As Elizabeth Cady Stanton suggested in 1869 , "sympathy as a civil agent is vague and powerless until caught and chained in logical . . . propositions, and coined into state law." The roots of congressional action, though, lay in the earlier period. Scholars point out that early Reconstruction legislation, in particular, the Thirteenth Amendment (adopted in 1865), was conceived in the context of a "vocabulary of freedom" that owed a good deal to abolitionist efforts. ${ }^{69}$

Significantly, the years 1865 and 1866 saw a resurgence of atrocity stories, now in the form of official reports from the Freedmen's Bureau and other federal agencies, documenting the continuing violence against freed slaves. One two-page segment of a much-publicized report by Gen. Carl Schurz, for example, documents shootings with bullets and buckshot, drownings, whippings, pursuit by patrols with dogs,

${ }^{67}$ Judith N. Shklar, Ordinary Vices (Cambridge, Mass., 1984), 7-44; Louis P. Masur, Rites of Execution: Capital Punishment and the Transformation of American Culture, 1776-1865 (New York, 1989), 50-70; Paul M. Spurlin, "Beccaria's Essay on Crimes and Punishments in Eighteenth-Century America," in Studies on Voltaire and the Eighteenth Century, 27 (Geneva, 1963), 1489-1504, esp. 1498-1504; Anthony F. Granucci, "Nor Cruel and Unusual Punishments Inflicted': The Original Meaning," California Law Review, 57 (Oct. 1969), 839-65.

${ }^{68}$ In suggesting that abolitionists should have recognized the brutality of wage labor as an analog to slavery, David Brion Davis seriously underestimates the importance of northern repugnance to governance through deliberately inflicted pain, in contrast to the liberating face of contract, which resonated strongly with the theme of voluntarism. See David Brion Davis, "The Preservation of English Liberty, I," in Antislavery Debate, ed. Bender, 65-103; and William Ellery Channing, "Remarks on the Slavery Question in a Letter to Jonathan Philips, Esq.," in Channing, Works, V, 5-106, esp. 37-38.

${ }^{69}$ Elizabeth Cady Stanton, "Speech to the McFarland-Richardson Protest Meeting," in Elizabeth Cady Stanton, Susan B. Anthony: Correspondence, Writings, Speeches, ed. Ellen C. DuBois (New York, 1981), 125-30, esp. 127; Harold M. Hyman and William M. Wiecek, Equal Justice under Law: Constitutional Development, 18351875 (New York, 1982), 390. See also William E. Nelson, "The Impact of the Antislavery Movement upon Styles of Judicial Reasoning in Nineteenth Century America," Harvard Law Review, 87 (Jan. 1974), 513-566; Howard Jay Graham, "The Early Antislavery Backgrounds of the Fourteenth Amendment, Part I," Wisconsin Law Review (May 1950), 479-507; Howard Jay Graham, "The Early Antislavery Backgrounds of the Fourteenth Amendment, Part II," ibid. (July 1950), 610-61. 
and hangings, often of multiple victims. These reports, often entered as official congressional documents, helped spur Congress to craft legislative or constitutional protection for the personal security of freed slaves. ${ }^{70}$ While they were often unable to protect free Black workers, Freedmen's Bureau agents from the top down identified corporal punishment as the incident of slavery most at odds with free status, and they issued orders that whipping be abolished as a form of labor discipline. One northerner proclaimed, "the day of the lash and corporal punishment is past, and must give way to law and moral power." 11

Congress responded to the ongoing persecution of freed slaves with the Civil Rights Act of 1866 and, in 1868, the Fourteenth Amendment. Both granted the federal government new powers to enforce the citizen's traditional right to state protection against private violence. In supporting those acts, many legislatorsincluding some who did not advocate the extension of political rights to former slaves-clearly intended to secure federal protection for the citizen's right to personal safety. ${ }^{72}$

In the event, political will flagged, and courts in the nineteenth century failed to develop the broad protective potential of the Thirteenth and Fourteenth amendments and the Civil Rights Act: some of the ugliest chapters in the history of American racial violence were written after their passage. But the Thirteenth Amendment and the Civil Rights Act in particular - the high-water marks of abolitionist sentiment - show clear intent to regulate, not just state action, but violence between private individuals bound together by legal status, specifically the systematized violence of slavery. The Civil Rights Act, for example, provided sanctions against individuals acting in a range of capacities, "under color of law, statute, ordinance, regulation, or custom." Such provisions helped dismantle the common law privileges and protections that constituted the master-slave relationship as a system of private ordering that virtually excluded the civil law. ${ }^{73}$

It is difficult to make larger normative claims for humanitarianism in the wake of works like Michel Foucault's brilliant Discipline and Punish. But Foucault's monolithic focus on forms of state power obscures particular uses of humanitarian thetoric

${ }^{70}$ U.S. Congress, Senate, Report of Maj. Gen. Carl Schurz on Condition of the South . . 39 Cong., 1 sess., doc. 2, Dec. 19, 1865, 18-19; U.S. Congress, House, Joint Committee on Reconstruction, Report of the Joint Committee on Reconstruction, 39 Cong., 1 sess., House Report 30, part iv, March 5, 1866, 82; Edward L. Ayers, Vengeance and Justice: Crime and Punishment in the 19th-Century American South (New York, 1984), 15165; Eric Foner, Reconstruction: America's Unfinished Revolution, 1863-1877 (New York, 1988), 119-23, 225.

${ }^{71}$ U.S. Congress, House, Committee on Freedmen's Affairs, Report of the Commissioners of the Freedmen's Bureau, 39 Cong., 1 sess., doc. 70, March 19, 1866, 147; George Bentley, History of the Freedmen's Bureau (New York, 1974), 27; Donald G. Nieman, To Set the Law in Motion: The Freedmen's Bureau and the Legal Rights of Blacks, 1865-1868 (Millwood, N.Y., 1979), 90-91; Foner, Reconstruction, 154-57, 165. In Foucaultian fashion, more modern types of bodily discipline also traveled under the cloak of reform: see William Leach, True Love and Perfect Union: The Feminist Reform of Sex and Society (New York, 1980), 19-98; and Abzug, Cosmos Crumbling, 163-82.

${ }^{72}$ Hyman and Wiecek, Equal Justice under Law, 295-334, 386-438; Foner, Reconstruction, 228-80; tenBroek, Equal under Law, 117-19, 157-239; Steven J. Heyman, "The First Duty of Government: Protection, Liberty, and the Fourteenth Amendment," Duke Law Journal, 41 (Dec. 1991), 507-71, esp. 545-70.

${ }^{73}$ Hyman and Wiecek, Equal Justice under Law, 437-515, esp. 437, 464; tenBroek, Equal under Law, 2034. Cf. Foner, Reconstruction, 245. 
in struggles against such figures as masters and patriarchs, who in their traditional roles were deputized to use violence against their subordinates. ${ }^{74} \mathrm{New}$ attitudes to cruelty embodied in social or legal norms did not herald a cessation of violence. But to the extent that weaker parties in status relationships could invoke the protection of the state-what legal scholars label "calling in the giant" - the new norms had redistributed power to benefit the more vulnerable at the expense of their aggressors. No judicial system ever excludes violence absolutely, but it does expand or contract categories of people who are protected from, or entitled to resort to, violence. The nineteenth-century United States saw a marked broadening in "rights" for the persons of slaves, women, and children through the piecemeal growth of protections at common law and by statute, state or private regulation, and constitutional amendment. Concepts of the rights of the person put into play during the antebellum era helped redraw the boundaries between acceptable and unacceptable violence, as ultimately reflected in broadened definitions of assault. They contributed much to the slow process of the constitutionalization of individual rights that has continued into this century. ${ }^{75}$

In addition to contributing to changed cultural norms, the rhetoric of sympathy for suffering also provided the basis for a now familiar style of legal reasoning, the argument for rights by analogy. While Revolution-era rights talk addressed the effects of oppressive behavior that harmed all citizens (if not all persons) equally, the history of nineteenth- and twentieth-century social movements has largely been the extension of rights to groups discriminated against on the basis of perceived differences. One of the most successful arguments in modern constitutional jurisprudence has been "I am like that person and so I deserve the same rights." But for that argument to succeed, the rights-bearing public must offer an answering embrace to the outsiders and bring them into the fold, even if only for limited purposes. Empathic identification - "that person is like me and so she deserves the same rights" - is critical to that response.

Before its arrival on the steps of the Supreme Court, this kind of moral reasoning became commonplace in less exalted circles. Pioneered by abolitionists, identification with suffering others was a central theme as well in antislavery sentimental fiction, which invoked slaves' sentient experience in a move to bring them within the compass of humanity. When one of the Quaker women sheltering the fugitive Eliza and George in Uncle Tom's Cabin is commended on her love of neighbor, she responds, 'Isn't it what we are made for? If I didn't love John and the Baby, I should not know how to feel for [Eliza]. ${ }^{176}$ Didactic tales, narratives, and sentimental

\footnotetext{
${ }^{74}$ Whatever Foucault believes about voluntary pain, my own position is that, until invited, not beating people is better than beating them. Michel Foucault, Discipline and Punish: The Birth of the Prison, trans. Alan Sheridan (New York, 1977).

${ }_{75}$ Andrew Fede, "Legitimized Violent Slave Abuse in the American South, 1619-1865: A Case Study of Law and Social Change in Six Southern States," American Journal of Legal History, 29 (April 1985), 93-150; Hartog, "Constitution of Aspiration." See also n66 above.

${ }^{76}$ For the quotation from Uncle Tom's Cabin, see Ashworth, "Relationship between Capitalism and Humanitarianism," 197. Chandler, Poetical Works, 23; Fisher, Hard Facts, 98-99.
} 
fiction urging white northern audiences to empathize with slaves' plight helped shape new moral perceptions of slaves as sentient beings, qualified to become rights-bearing individuals.

On a more cautious note, the widespread imagery of the brutalized slave may also have delimited the political will and imagination when it came time to define the scope of free Blacks' new "rights" on paper. The repetitious images of slaves' degradation may have worked to set them apart as a class in the viewer's mind, to constitute difference rather than to obliterate it: certainly freed Blacks themselves dropped the suffering stance when it had done its work. ${ }^{77}$ At the very least, an emphasis on the "right" to physical autonomy proved a poor stand-in for a more comprehensive vision of social and economic justice: private wrongs beget private remedies. The emphasis on relieving the violence of slavery may have "retarded the development of a vocabulary that could depict more subtle forms of coercion, oppression, and class rule."78

Nonetheless, abolitionists used narratives of slave suffering to help bring about a change in conventions of moral reasoning that underlay rights claims, specifically in conventions about individuals' right to protection from bodily abuse. Humanitarians were not always humane, and the career of "rights" has been far more checkered than abolitionists could have foretold. But for better and for worse, this strategy contributed substantially to the growing power of individual rights within our system of jurisprudence.

77 Andrews, "Representation of Slavery," 62-66. Thanks to Robert Orsi for a very eloquent letter on the limitations imposed by the role of the sufferer.

${ }^{78}$ David Brion Davis, "Reflections on Abolitionism and Ideological Hegemony," in Antislavery Debate, ed. Bender, 161-79, esp. 176. 